\title{
Extracting the most from terrestrial plant-derived $n$-alkyl lipids and their carbon isotopes from the sedimentary record: A review
}

Aaron F. Diefendorf*, Erika J. Freimuth

Keywords: carbon isotope excursions, carbon cycle, $n$-alkanes, leaf wax, plant wax, compound-specific isotope analysis, Cenozoic

(C) 2016. This manuscript version is made available under the Elsevier user license http://www.elsevier.com/open-access/userlicense/1.0/ 


\begin{abstract}
Terrestrial plant biomarkers and their carbon isotopes provide insights into carbon cycling, paleovegetation and paleoclimate, ranging in scale from local to global. Over the past decade, considerable efforts have been made to constrain the factors that influence plant biomarkers and their

| carbon isotope composition to improve their utility for paleo applications. Global and regional replication of time intervals of great interest, such as during carbon cycle perturbations, has increased the need to I compare among sites, but doing so has also complicated interpretation of carbon cycle perturbations due to the differences among records. This has led to questions regarding the fidelity of isotope records, the sensitivity of the isotope record to climate, and the best practices for reconciling records. But, at the same time, it has led to new exciting information on ecosystem responses to climate change. By removing competing influences of climate, ecosystem and biology, modern biomarker and isotope calibrations provide a means of reconciling and improving paleorecords and placing quantitative constraints on their interpretation. Here, we review the factors that influence the concentration of plant biomarkers and their carbon isotope composition and provide best practice for reconciling biomarker carbon isotope records for interpreting climate, ecosystem, and carbon cycling in the geologic past.
\end{abstract}




\section{Introduction}

Plant biomarkers have been recognized for decades in the sedimentary record. Since their discovery, they

| have developed into an important tool for organic geochemists to reconstruct paleoclimate and paleovegetation change, especially when other lines of evidence, such as pollen or macrofossils, are poorly preserved. Of these biomarkers, long chain $n$-alkyl plant wax compounds are the most commonly used. Their utility is strengthened both by excellent preservation potential in lacustrine, terrestrial and nearshore marine sediments and rocks, and by relatively easy extraction and analysis. Their carbon isotopic composition provides additional information as it passes evidence about the carbon cycle, vegetation, and climate to the geologic record.

Much of what we know about the carbon isotopic signals preserved in sedimentary plant wax are inferred from studies made on individual living species. However, sediments accumulate mixtures of wax from individual plants that are integrated at scales ranging from small ecosystems to large basins. In large spatial scale studies, plant wax may represent integrated signals of one to many biomes. This poses challenges when interpreting plant wax with species-level information (the focus of almost all calibration studies) because scaling relationships have not been developed between species, ecosystems and biomes. The role that vegetation, climate, taphonomy and transport have on plant wax concentration and carbon isotopic composition complicates interpretation of sedimentary plant wax. The evolution of plants and plant biomarkers over the past several hundred million years can also not be overlooked, although some level of biological uniformitarianism must be assumed.

Comparison of plant wax carbon isotopes among records for discrete geologic events, such as the Paleocene-Eocene thermal maximum, indicate that plant wax carbon isotopes are not only sensitive to carbon cycle perturbation, but are sensitive to vegetation and climate (e.g. Schouten et al., 2007; Diefendorf et al., 2010; McInerney and Wing, 2011; Tipple et al., 2011; Krishnan et al., 2015; Schoon et al., 2015). Other factors, such as lags in the ages of plant wax contributions, may also be important, especially for more recent sediments due to their relatively high temporal resolution (Pearson and 
Eglinton, 2000; Uchikawa et al., 2008; Galy and Eglinton, 2011; Douglas et al., 2014). Changes in vegetation composition become even more important after the rise of angiosperms in the Cretaceous and then the rise of $\mathrm{C}_{4}$ plants in the Miocene (Edwards et al., 2010).

This review focuses on the current state of knowledge about terrestrial plant biomarkers and how this

| information can be used to better interpret past changes in paleoclimate, paleovegetation and the carbon cycle. Section 2 provides background on the factors that influence plant wax $n$-alkyl lipids. Much of what we know about plant biomarkers is based on $n$-alkanes, although other wax components, such as $n$ alkanoic acids and $n$-alkanols, are also informative, especially for more recent sediments (Feakins et al., 2007; Douglas et al., 2012; Sachse et al., 2012). Section 3 focuses on the factors that influence plant carbon isotopic composition. The organizational structure for the isotope section follows the flow of carbon from the atmosphere to plant biomarkers and on to the integration and preservation of biomarkers in the sedimentary archive (Fig. 1). Section 4 focuses on applications in the paleorecord for interpreting plant carbon isotopes as paleoclimate, paleovegetation and atmospheric $\delta^{13} \mathrm{C}$ proxies. Section 5 provides a summary, remaining gaps and future directions. The review does not include the hydrogen isotopic composition of plant wax compoents, which has been reviewed recently (Sachse et al., 2012; Sessions, 2016).

\section{Plant wax $n$-alkyl lipids}

The cuticular wax of terrestrial vascular plant leaves is composed of long chain $n$-alkyl compounds, including $n$-alkanes, $n$-alkanoic acids, $n$-alkanols and $n$-esters (Eglinton et al., 1962; Eglinton and Hamilton, 1967; Kolattukudy et al., 1976; Jetter et al., 2000). Many of these compounds can be found on the surface of other plant organs, but in almost all cases, the concentration of long chain wax components is significantly lower than in the corresponding leaves. Therefore, based on concentration and biomass, the leaf wax from trees, shrubs and grasses can generally be assumed to be the dominant source of wax delivered to sediments (e.g. Mueller et al., 2012; Gamarra and Kahmen, 2015). We recommend the term 'plant wax' when referring more generally to wax components sourced from plants, especially when the 
components are found in soils and sediments, and the term 'leaf wax' when specifically referring to lipids sampled directly from leaves.

I Plant waxes are biosynthesized in the acetogenic pathway from acetyl coenzyme-A (acetyl CoA) to produce short chain $n$-alkanoic acids that are then elongated through repeated additions of acetyl CoA. $n$ Alkanoic acids are then converted to $n$-alkanes by enzymatic decarboxylation or to $n$-alkanols by reduction (Eglinton and Hamilton, 1967; Kolattukudy et al., 1976; Kolattukudy, 1996; Kunst and Samuels, 2003; Chikaraishi et al., 2004b). The functions of plant waxes are diverse and include forming a barrier to inhibit water loss, acting as a barrier to chemicals, and providing protection from disease and ultraviolet light (Eglinton and Hamilton, 1967; Kerstiens, 1996; Riederer and Schreiber, 2001; Muller and Riederer, 2005; Bargel et al., 2006; Riederer and Muller, 2006). The reader is referred to the extensive review of cuticular wax function by Koch and Ensikat (2008) and references therein.

Relatively few studies of plant waxes in extant plants have compared the relative abundance and carbon isotopic composition of two or more compound classes (Chikaraishi et al., 2004b; Chikaraishi and Naraoka, 2006, 2007; Rommerskirchen et al., 2006; Vogts et al., 2009; Gao et al., 2015). Surveys of plant waxes in extant plants indicate that the molecular composition and concentration vary among plant species for $n$-alkanes and $n$-alkanols. In contrast, the total concentration of $n$-alkanoic acids is more consistent among trees and shrubs (Polissar and Freeman, 2010; Diefendorf et al., 201, 2015b; Bush and McInerney, 2013; Polissar et al., 2014).

| In general, long chain $n$-alkane abundances (i.e. $n-\mathrm{C}_{25}$ and above) are typically higher in angiosperm trees and shrubs than in many gymnosperms, and more specifically, conifers (Fig. 2; Table 1; Supplementary material, Table E-1). However, it is critical to take into account which conifers are present within a plant community. For example, Pinaceae and the Taxodioid group in Cupressaceae synthesize low concentrations of $n$-alkanes, whereas Araucariaceae, Podocarpaceae, Taxaceae, and the Cupressoideae and Callitroideae groups within Cupressaceae have $n$-alkane concentrations that rival those of 
angiosperms (Fig. 3). Much of this variation among conifer families can be attributed to the evolutionary history of conifers (Diefendorf et al., 2015b).

Evaluating the contributions of plant waxes from conifers is important as conifer assemblages change in time and space. For example, today in North America, most conifers are Pinaceae and thus have low concentrations of $n$-alkanes. Other species, such as Juniperus communis and Thuja plicata, are important and have high concentrations, but are typically not the dominant species within an ecosystem (Diefendorf et al., 2011; Tipple and Pagani, 2013; Diefendorf et al., 2015b). However, in the past, this was not always the case. For example, Juniperus was common in upland environments in the Oligocene Creede I Formation (Axelrod, 1987; Wolfe and Schorn, 1990), so could be the dominant source of long chain $n$ alkanes.

Other growth forms and groups, besides woody angiosperms, produce significant quantities of plant I waxes (Fig. 2). For example, $n$-alkanes are found in grasses, succulents, herbs and ferns (Lytle et al., 1976; Rommerskirchen et al., 2006; Vogts et al., 2009; Bush and McInerney, 2013; Carr et al., 2014).

| Cycads do not, however, appear to be a significant source (Vane et al., 2014). Aquatic macrophytes, including submerged, floating and emergent growth habits, also produce $n$-alkyl lipids, with $n$-alkanes being the most diagnostic compound class to distinguish aquatic from terrestrial plant sources (Ficken et I al., 2000). Aquatic macrophytes are typically dominated by mid-chain homologs (Baas et al., 2000; Ficken et al., 2000; Nott et al., 2000) and can be a major source of $n-\mathrm{C}_{23}$ and $n-\mathrm{C}_{25}$ in sediments (Aichner et al., 2010). Generally, aquatic plants favor production of longer $n$-alkane homologues in emergent relative to submerged or floating growth forms (Mead et al., 2005). The Sphagnum moss species, common along bog shorelines, are also generally dominated by $n-\mathrm{C}_{23}$ and $n$ - $\mathrm{C}_{25}$ (Baas et al., 2000; Nott et al., 2000). However, significant inter-species variation has been observed, with certain species maximizing at $n-\mathrm{C}_{31}$ (Baas et al., 2000; Bingham et al., 2010) or favoring higher $n$ - $\mathrm{C}_{31}$ alkane concentration on relatively dry growth substrates such as hummocks (Nichols et al., 2006). 
| Several metrics have been developed to distinguish aquatic and terrestrial sources using plant wax distributions in sediments. These include the $P_{\text {aq }}$ ratio of $n$-alkane homologues to quantify the contribution of submerged and floating macrophytes relative to emergent and terrestrial plants (Ficken et al., 2000) and, in peat bogs, $n-\mathrm{C}_{23} / n-\mathrm{C}_{25}$ ratio values to reflect bog wetness (Bingham et al., 2010), and the ratio of $n-\mathrm{C}_{23}$ to $n-\mathrm{C}_{31}$ (Nott et al., 2000) or $n-\mathrm{C}_{33}$ (Pancost et al., 2002) to indicate the proportion of Sphagnum inputs. Application of these and other indicators based on plant wax molecular distribution must consider whether the depositional setting and plant sources are comparable to metric calibrations. Emergent and terrestrial plants contain 5-10 x higher lipid concentration than submerged species (e.g. Aichner et al., 2010). Therefore, terrestrial plants remain the focus of this review as the dominant source of long chain $n$ alkyl lipids in sediments.

The composition of $n$-alkanes also varies between $\mathrm{C}_{3}$ and $\mathrm{C}_{4}$ grasses. For example, $\mathrm{C}_{4}$ grasses tend to | have higher concentrations of longer chain $n$-alkanes $\left(\mathrm{C}_{31}, \mathrm{C}_{33}, \mathrm{C}_{35}\right)$ than $\mathrm{C}_{3}$ grasses and woody angiosperms (Krull et al., 2006; Rommerskirchen et al., 2006; Vogts et al., 2009; Garcin et al., 2014). The compositional differences between $\mathrm{C}_{3}$ and $\mathrm{C}_{4}$ grasses are important in the context of evaluating Miocene and younger sediments (Edwards et al., 2010).

The composition of $n$-alkanes is commonly compared among plants using the average chain length | (ACL):

where $m$ and $n$ represent the shortest and longest chain length, respectively. ACL has been used in I geologic studies as both a vegetation and climate proxy. However, ACL studies of extant plants indicate that both biology and climate may influence ACL values (see reviews by Freeman and Pancost, 2014; Bush and McInerney, 2015), but not always in clear or consistent ways. For example, Hoffmann et al. (2013) found that climate influenced ACL in opposite ways for two plant genera along the same climate transect in Australia. At a global scale, temperature does not appear to be a strong control on ACL (Fig. 4), likely because of differences in ACL among species. Although no clear patterns emerge when 
comparing ACL with angiosperm phylogeny, conifer ACL has a strong phylogenetic signal (Diefendorf et al., 2015a). Very long chain $n$-alkanes $\left(\mathrm{C}_{33}, \mathrm{C}_{35}\right)$ may be a good indicator for $\mathrm{C}_{4}$ grasses in grassland ecosystems (Vogts et al., 2012). However, it is important to highlight that some conifers also make very

| long chain $n$-alkanes ( $\mathrm{C}_{33}$ to $\mathrm{C}_{37}$; Fig. 3) (Diefendorf et al., 2015b).

Based on our current knowledge about the factors that influence plant waxes concentrations, interpreting long chain $n$-alkanes as vegetation indicators should be done cautiously with respect to phylogeny, climate and biome (Diefendorf et al., 2011; Freeman and Pancost, 2014; Chevalier et al., 2015;

Diefendorf et al., 2015b). Nonetheless, in some biomes or biome transitions through time, it may be possible to exploit differences in chain length distributions between plant groups to constrain plant wax source and to provide group specific $\delta^{13} \mathrm{C}$ values. For example, it may be possible to use $n-\mathrm{C}_{29}$ alkane as a $\mathrm{C}_{3}$ biomarker and $n-\mathrm{C}_{33}$ and $n-\mathrm{C}_{35}$ alkanes as $\mathrm{C}_{4}$ biomarkers to reconstruct $\mathrm{C}_{3} / \mathrm{C}_{4}$ plant cover (e.g. Garcin et al., 2014). This may also be useful when evaluating the rise of $\mathrm{C}_{4}$ plants in the Miocene (e.g. Freeman and Colarusso, 2001; Uno et al., 2016a,b).

\section{Controls on plant carbon isotopes and waxes}

This section provides a basis for the factors that control the carbon isotopic composition of plant waxes from the source of carbon, atmospheric $\mathrm{CO}_{2}$, to the integration and deposition of plant lipids in sediments.

| The organization of this section follows the pathway outlined in Fig. 1. Although this section is not exhaustive, it provides a solid basis for the factors that influence sedimentary plant wax $\delta^{13} \mathrm{C}$ values.

\subsection{Atmospheric ${ }^{13} \mathrm{CO}_{2}$}

In any analysis of plant $\delta^{13} \mathrm{C}$ values from the geologic past, it is critical to constrain changes in the $\delta^{13} \mathrm{C}$

I value of atmospheric $\mathrm{CO}_{2}\left(\delta^{13} \mathrm{C}_{\mathrm{atm}}\right)$ as this sets the starting isotopic composition for plant carbon. The best practices for estimating past $\delta^{13} \mathrm{C}_{\mathrm{atm}}$ values were explored by Tipple et al. (2010). Based on their

I recommendations, it is best to determine $\delta^{13} \mathrm{C}_{\text {atm }}$ from carbonate $\delta^{13} \mathrm{C}$ values of benthic foraminifera 
sampled from marine cores. The approach requires estimates of ocean temperature values to correct for fractionation. To that end, Tipple et al. (2010) provided $\delta^{13} \mathrm{C}_{\mathrm{atm}}$ values from benthic foraminifera for the

I Cenozoic. For studies that focus on more recent sediments $(<50 \mathrm{ka})$, ice core ${ }^{13} \mathrm{CO}_{2}$ records are preferable as they are at a higher resolution than marine sediments and provide a more direct sampling technique.

Over the Cenozoic, $\delta^{13} \mathrm{C}_{\text {atm }}$ varies by up to $2 \%$ (Fig. 5) and thus significantly deviates from the preindustrial value of $-6.5 \%$. The changes reflect both long term and short term changes in the carbon cycle as a function of carbon source (volcanism, weathering of organic C), burial, weathering and changes in marine photosynthetic fractionation (Kump and Arthur, 1999). Constraining these factors is especially important during periods of large change, such as during the Miocene and early Paleogene. The former is especially important for studies evaluating changes in $\mathrm{C}_{3}$ and $\mathrm{C}_{4}$ vegetation based on $\delta^{13} \mathrm{C}$ values (Tipple et al., 2010). Constraining $\delta^{13} \mathrm{C}_{\text {atm }}$ during periods of rapid carbon cycle perturbations, such as the hyperthermal events in the early Eocene, is more challenging given the rapid feedbacks and imbalances in the carbon cycle that occur on short timescales (McInerney and Wing, 2011; Bowen, 2013).

\subsection{Plant carbon isotopes}

During photosynthetic carbon fixation, atmospheric $\mathrm{CO}_{2}$ is converted to sugars by the enzyme Rubisco, which fractionates strongly against ${ }^{13} \mathrm{C}$. Plant carbon therefore has lower $\delta^{13} \mathrm{C}$ values than atmospheric $\mathrm{CO}_{2}$ and other inorganic carbon reservoirs in ocean waters, sediments and rocks. Along with Rubisco, other factors influence the size of the fractionation. Photosynthetic pathway is the largest of these. Plants that use the $\mathrm{C}_{3}$ carbon fixation pathway (Calvin-Benson) have the largest net fractionation, whereas plants that use the $\mathrm{C}_{4}$ carbon fixation pathway (Hatch-Slack) have the smallest net fractionation. Plants using Crassulacean acid metabolism (CAM) have intermediate fractionation, ranging from large to small during daytime and nocturnal $\mathrm{CO}_{2}$ fixation modes, respectively (O'Leary, 1981). Other factors such as plant | physiology, climate and ecology have considerable influence on net photosynthetic fractionation and are discussed below in the context of photosynthetic pathway. 
3.2.1. $\mathrm{C}_{3}$ plants and ${ }^{13} \mathrm{C}$ photosynthetic fractionation

In the $\mathrm{C}_{3}$ pathway, Rubisco (O'Leary, 1981), along with other factors (diffusion, mesophyll and stomatal conductance), results in a large net isotope effect (e.g. Farquhar et al., 1989). The fractionation is commonly expressed as discrimination $\left(\Delta_{\text {leaf }}\right)$ where:

\section{Eq. 1}

Recent recommendations for the reporting of stable isotopic fractionation prefer the usage of $\alpha$ or $\varepsilon$ notation (Coplen, 2011). Importantly, $\Delta_{\text {leaf }}$ is based on the $\varepsilon$ notation where:

and is therefore an exact measure of $\alpha . \Delta_{\text {leaf }}$ should not be confused with the common geologic usage of $\Delta$ as the difference between $\delta_{\mathrm{a}}$ and $\delta_{\mathrm{b}}$, which is not exact and should not be used. Therefore, the usage of $\Delta_{\text {leaf }}$ is appropriate given the large body of ecological literature. For clarity, when reporting $\Delta_{\text {leaf }}$ values, the $\Delta_{\text {leaf }}$ equation should be provided.

The $\Delta_{\text {leaf }}$ of $C_{3}$ plants is often expressed using the reduced linear relationship of Farquhar et al. (1982) that I incorporates fractionation associated with $\mathrm{C}$ fixation and the ratio of the $\mathrm{CO}_{2}$ concentration (as partial pressures) in the internal stomatal cavity $\left(C_{i}\right)$ to the atmosphere $\left(C_{a}\right)$ as:

Eq. 3

where $a$ is the fractionation associated with $\mathrm{CO}_{2}$ diffusion in air through the stomatal opening (4.4\%;

O'Leary, 1981) and $b$ the net fractionation associated with fixation. The term $b$ in Eq. 3 is not a constant, as is often assumed, as it reflects the balance between fractionation by Rubisco and PEP carboxylase 
(Farquhar and Richards, 1984). Values for $b$ therefore vary between plants and experiment procedures, | but are often assumed to range between 27 and 30\%o (e.g. Farquhar et al., 1989; Lloyd and Farquhar, 1994). $C_{i}$ depends on the flux of $\mathrm{CO}_{2}$ into the leaf and is regulated by stomatal conductance and the flux of $\mathrm{CO}_{2}$ removed by $\mathrm{C}$ fixation through assimilation (Farquhar et al., 1982). $C_{i}$ can be directly proportional to $\Delta_{\text {leaf }}$ when $C_{a}$ and $b$ are held constant, but see Seibt et al. (2008). $\Delta_{\text {leaf }}$ generally decreases with decreasing water availability as stomatal conductance is decreased and water use efficiency is increased | (Farquhar et al., 1989), although changes in $C_{a}$ and mesophyll conductance may complicate the relationship (Ehleringer and Cerling, 1995; Warren and Adams, 2006; Seibt et al., 2008). $\Delta_{\text {leaf }}$ is sensitive to many factors in addition to water availability, including plant type, light intensity, nutrient status, canopy effects and $\mathrm{CO}_{2}$ partial pressure (Farquhar et al., 1989; Diefendorf et al., 2010; Schubert and Jahren, 2012; Cernusak et al., 2013; Graham et al., 2014).

I As mentioned above, $\Delta_{\text {leaf }}$ is strongly related to water availability for $\mathrm{C}_{3}$ plants (e.g. Ehleringer et al., 1992; Stewart et al., 1995; Warren et al., 2001; Bowling et al., 2002; Prentice et al., 2011b). Diefendorf et al. (2010) identified mean annual precipitation (MAP) as the strongest single control on $\Delta_{\text {leaf }}$ in a global I dataset $\left(\mathrm{R}^{2} 0.55, p<0.0001\right)$. In that study, they found that MAP was a stronger predictor of $\Delta_{\text {leaf }}$ than other climate and geographic indicators alone (temperature, humidity, soil available moisture, latitude, etc.). When the influence of altitude is included, the relationship increases to $\mathrm{R}^{2} 0.61(p<0.0001)$. In a different study, Kohn (2010) found a similar relationship between $\Delta_{\text {leaf }}$ and MAP ( $\left.\mathrm{R}^{2} 0.59\right)$, when also taking into account altitude and latitude (see also Freeman et al., 2011). Although these patterns emerge in large global datasets, it is important to note that large $\Delta_{\text {leaf }}$ ranges in $\mathrm{C}_{3}$ plants are common, even at a single site. For example, several sites in the tropics have a range of ca. $8 \%$ among species, even when sampling is restricted to sun-exposed upper canopy leaves (note the range in $\Delta_{\text {leaf }}$ at ca. $3000 \mathrm{~mm} / \mathrm{yr}$ in Fig. 6). Much of this variation among species can be explained by genetic variability or small scale changes in water availability (Ehleringer et al., 1991; Bonal et al., 2000). However, it is unclear how this range in values at a single site would influence plant carbon isotopes integrated in the sedimentary record. 
| $\Delta_{\text {leaf }}$ varies among different plant types. For example, conifers have lower $\Delta_{\text {leaf }}$ values than angiosperms (Leavitt and Newberry, 1992; Brooks et al., 1997; Murray et al., 1998). The difference between angiosperm and conifer $\Delta_{\text {leaf }}$ grown at the same site (to remove environmental influences on $\Delta_{\text {leaf }}$ ) is ca. 2.7\%o (Diefendorf et al., 2010). Importantly, this difference is not fixed because the relationship between $\Delta_{\text {leaf }}$ and MAP is unique for angiosperms and conifers, likely reflecting the different growth strategies and water use efficiency of these two major taxonomic groups. At the ecosystem scale, $\Delta_{\text {leaf }}$ significantly varies among biomes (Fig. 6, reflecting the importance of climate and vegetation (Lloyd and Farquhar, 1994; Kaplan et al., 2002; Diefendorf et al., 2010).

\subsubsection{Atmospheric $\mathrm{CO}_{2}$ concentration and $\mathrm{C}_{3}$ plants}

The effect of $p \mathrm{CO}_{2}$ on $\Delta_{\text {leaf }}$ has been of interest to isotope geochemists for some time given the relationship between fractionation and $C_{a}$ in Eq. 3. Unfortunately, the relationship between $p \mathrm{CO}_{2}$ and $\Delta_{\text {leaf }}$ has remained enigmatic (e.g. Körner et al., 1991; Ehleringer and Cerling, 1995; Polley et al., 1995). This may have something to do with the timescales at which these measurements are made (Beerling and Royer, 2002; Franks and Beerling, 2009), or because water availability is often unconstrained (Körner, | 2007). On very short timescales, plants optimize leaf gas exchange, thereby modifying $C_{i} / C_{a}$, to increase assimilation and water use efficiency (Lammertsma et al., 2011). However, on timescales of decades, plants respond to changing $p \mathrm{CO}_{2}$ by adjusting optimal stomatal size and density and by regulating the rate

I of carbon fixation to maintain optimal set points, including internal to external $\mathrm{CO}_{2}$ concentration $\left(C_{i} / C_{a}\right)$ (Woodward, 1987; Ehleringer and Cerling, 1995; Woodward and Kelly, 1995; Beerling, 1996; Franks and Beerling, 2009; Franks et al., 2014), which results in a complex response of $C_{i}$ relative to $C_{a}$ (Seibt et al., 2008; Voelker et al., 2016). Indeed, recent growth chamber studies have identified a strong relationship between $p \mathrm{CO}_{2}$ and $\Delta_{\text {leaf }}$ for plants grown over one life cycle (Schubert and Jahren, 2012). However,

I studies that have focused on long term changes (>100 yr) in stomatal conductance and $\Delta_{\text {leaf }}$ have observed a small decrease in $\Delta_{\text {leaf }}$ as $p \mathrm{CO}_{2}$ increases (Peñuelas and Azcónbieto, 1992; Bert et al., 1997; Duquesnay et al., 1998; Arneth et al., 2002; Saurer et al., 2004). 
On much longer timescales, Diefendorf et al. (2015a) found that Paleogene $\Delta_{\text {leaf }}$ values are consistent with water availability and taxonomic group and do not appear to respond to change in $p \mathrm{CO}_{2}$. If $C_{i} / C_{a}$ is largely maintained over long timescales (Franks and Beerling, 2009; Franks et al., 2014), despite a large change in $p \mathrm{CO}_{2}$, then that would explain the similarity in fossil $\delta^{13} \mathrm{C}$ values over long periods of Earth history (Deines, 1980; Peters-Kottig et al., 2006), despite large changes in $p \mathrm{CO}_{2}$ (Berner and Kothavala, 2001). The stability of terrestrial plant carbon isotope values over geologic time thus may indicate that optimum $\Delta_{\text {leaf }}$ values are maintained on long geologic timescales, as suggested by Ehleringer and Cerling (1995).

\subsection{3. $C_{4}$ plants and ${ }^{13} \mathrm{C}$ photosynthetic fractionation}

Plants utilizing the $\mathrm{C}_{4}$ photosynthetic pathway incorporate a $\mathrm{CO}_{2}$ concentrating mechanism, along with biochemical and structural modifications, to ultimately fix $\mathrm{C}$ using the Calvin-Benson cycle. In this pathway, $\mathrm{CO}_{2}$ is converted to aqueous $\mathrm{HCO}_{3}{ }^{-}$and then fixed via carboxylation of phosphoenolpyruvate

| (PEP) by PEP-carboxylase (PEP-C) to produce the four carbon acid, oxaloacetate. Oxaloacetate is then reduced to either malate or aspartate and is then exported from the outer mesophyll cells to the inner bundle-sheath cells. In the bundle-sheath cells, the acids are decarboxylated, thereby releasing $\mathrm{CO}_{2}$, which is then fixed in the Calvin-Benson cycle. This process results in a high concentration of $\mathrm{CO}_{2}$ that saturates Rubisco, so a greater proportion of $\mathrm{C}$ is fixed compared with $\mathrm{C}_{3}$ photosynthesis (Hatch, 1987). Photorespiration is also reduced or eliminated in the $\mathrm{C}_{4}$ pathway because PEP-C has a high affinity for

I $\mathrm{CO}_{2}$ and not $\mathrm{O}_{2}$, thereby excluding $\mathrm{O}_{2}$ transfer to the bundle-sheath cells. Because of these biochemical and structural modifications, $\mathrm{C}_{4}$ plants have a physiological advantage over $\mathrm{C}_{3}$ plants at present day | atmospheric $\mathrm{CO}_{2}$ concentrations, especially in hot, high-light, and dry environments (Sage et al., 1999). The rise and evolution of $\mathrm{C}_{4}$ plants in the Miocene has been reviewed extensively (Tipple and Pagani, 2007; Edwards et al., 2010).

The fractionation that occurs during $\mathrm{C}_{4}$ photosynthesis has been described by Farquhar (1983): 
and is related to the small fractionation associated with carboxylation by PEP-C $\left(-5.7 \%\right.$; $\left.b_{4}\right)$, Rubisco $(b)$, the proportion of $\mathrm{CO}_{2}$ that leaks out of the bundle-sheath cell $(\phi)$, the diffusion of $\mathrm{CO}_{2}$ in air $(a)$, and the internal to atmospheric $\mathrm{CO}_{2}$ concentration $\left(C_{i} / C_{a}\right)$. Because only a small amount of $\mathrm{CO}_{2}$ leaks out of the bundle-sheath cell, the isotope effect of Rubisco is not fully expressed, so total fractionation is small (Farquhar et al., 1989). $\Delta_{\text {leaf }}$ variation in $\mathrm{C}_{4}$ plants is related to which enzymes are utilized in oxaloacetate

I conversion, which varies among species, and to variation in the leakiness of the bundle-sheath cells among different $\mathrm{C}_{4}$ plant species (Hattersley, 1982; Farquhar, 1983). As a result, carbon isotopic

I fractionation in $\mathrm{C}_{4}$ plants is very tightly controlled and results in a small range in $\delta^{13} \mathrm{C}$ values vs. $\mathrm{C}_{3}$ plants (Fig. 7) (Tipple and Pagani, 2007).

\subsubsection{CAM plants and ${ }^{13} \mathrm{C}$ photosynthetic fractionation}

While CAM plants are most abundant in the subtropics and tropics, their range extends to temperate zones and high latitudes (Teeri et al., 1978; Lüttge, 2004). Their physiology is adapted to stress tolerance rather than ecosystem dominance (Lüttge, 2004), so CAM biomass productivity is low vs. $\mathrm{C}_{3}$ or $\mathrm{C}_{4}$ plants (Black, 1973). Therefore, $\mathrm{C}_{3}$ and $\mathrm{C}_{4}$ terrestrial plants would be the major contributors to sedimentary long chain $n$-alkyl lipid records for almost all ecosystems and biomes. The reader is referred to detailed | information regarding ${ }^{13} \mathrm{C}$ fractionation in CAM and aquatic plants described by Farquhar et al. (1989).

\section{3. ${ }^{13} \mathrm{C}$ fractionation during plant wax biosynthesis}

The fractionation that occurs during lipid biosynthesis is related to isotope effects associated with numerous biochemical steps involved in the creation of complex lipids from basic organic precursor molecules. Biosynthetic fractionation is also controlled by the starting isotope composition of the carbon source, precursor availability and downstream reaction pathways (Hayes, 2001; Chikaraishi et al., 2004a,b). Fractionation during biosynthesis is commonly measured using $\varepsilon_{\text {lipid }}$ notation: 
where the carbon isotopic composition of the lipid of interest is compared with bulk leaf tissue (Chikaraishi et al., 2004b). Measuring biosynthetic fractionation as a function of the carbon isotopic compositions of lipid and leaf has the advantage that the complexities of fractionation during photosynthesis, which are controlled by the many factors outlined above, is treated separately. This has many advantages for paleo applications utilizing the carbon isotopic composition of lipids as a measure of plant carbon and/or $\Delta_{\text {leaf. }}$

For $n$-alkanes, the range in $\varepsilon_{n \text {-alkanes-leaf }}$ can be large (ca. 10\%o) among species, even when grown under

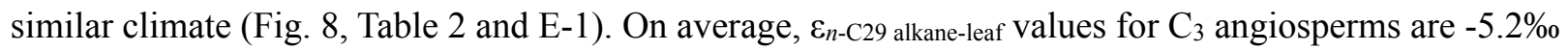
for trees, $-6.0 \%$ for graminoids, $-7.3 \%$ for forbs and $-7.4 \%$ for shrubs, whereas $\mathrm{C}_{4}$ graminoids have much more negative values at $-9.3 \%$. Although data are sparse, there is some suggestion that the ${ }^{13} \mathrm{C}$ fractionation is similar for CAM and $\mathrm{C}_{4}$ plant $n$-alkanes and $n$-alkanoic acids (Collister et al., 1994b; Chikaraishi et al., 2004a).

Recent studies have suggested that these values vary among climates, with greater fractionation in tropical and subtropical plants than temperate plants (Magill et al., 2013; Freeman and Pancost, 2014). Indeed, this is true when evaluating among all $\mathrm{C}_{3}$ plants. For example, $\mathrm{C}_{3}$ angiosperms have greater $n$ - $\mathrm{C}_{29}$ alkane fractionation in tropical and subtropical latitudes $(-6.2 \%)$ than in temperate latitudes $(-4.9 \%$; $t$ test, $p=0.002$ ). However, when comparing individual growth forms among latitudinal zones, these differences diminish. For example, for the largest group of growth forms, temperate angiosperm $\mathrm{C}_{3}$ trees, values are $-5.5 \%$ in tropical and subtropical latitudes and $-4.6 \%$ in temperate latitudes. The means between these zones are different ( $t$-test, $p=0.05)$. The comparisons between zones appear to be related to the presence or absence of specific growth forms. For example, shrubs, lianas and forbs are nearly all from tropical and subtropical latitudes and have on average more negative $\varepsilon_{n}$-C29 alkane-leaf values than trees. 
Within temperate zones, conifer trees have smaller $\varepsilon_{n-\mathrm{C} 29}$ alkane-leaf values $(-2.5 \%$ o) than angiosperm trees $(-4.5 \%$ ) growing at the same site (Diefendorf et al., 2011). However, that study reported on conifer species that were largely biased to North America. Among a larger set of plants, conifers appear to have greater fractionation (-4.2\%) and are more similar to angiosperm trees (-5.2\%o; Table 2, Fig. 8), although

| mean values are different ( $t$-test, $p=0.04)$. In a more recent study, Diefendorf et al. (2015b) analyzed a large set of conifer species, including many subtropical and Southern Hemisphere conifers, all growing at

| the same site in California. In that study, the authors measured a wide range in $\varepsilon_{n \text {-alkanes-leaf values among }}$ conifer families (Fig. 9) with the smallest fractionation in Pinaceae (pines), medium fractionation in

I Cupressaceae (junipers and relatives) and large fractionation in Taxaceae (yews). An analysis of $\varepsilon_{n \text {-alkanes- }}$ leaf values indicates that there is a significant phylogenetic signal in the data. Therefore, it seems likely

| that carbon metabolism or subtle biochemical variation among conifer clades are responsible, at least in part, for this pattern (Diefendorf et al., 2015b).

Freeman and Pancost (2014) suggest that differences in carbon storage and allocation could explain differences among plant types, growth strategy and climate regions. Indeed, many factors are likely

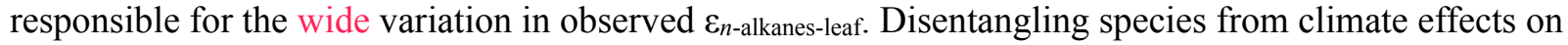

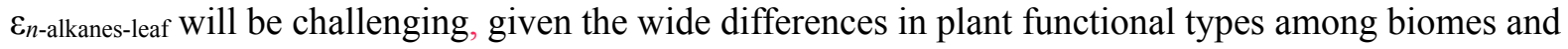

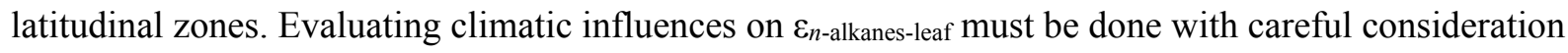
for variations in plant functional type and may also require phylogenetic control (Diefendorf et al., $2015 b)$. This is especially important for trying to determine if coordinated variations in $\Delta_{\text {leaf }}$ and $\varepsilon_{n \text {-alkanes- }}$ leaf exist.

| The biosynthetic fractionation factors for $n$-alkanoic acids have been measured for only a few species (Chikaraishi et al., 2004a; Chikaraishi and Naraoka, 2006; Dungait et al., 2008) and future studies are required to fill in this gap.

\subsection{Waxes from plants to sediments to rocks}


While recent advances have improved understanding of environmental and biological factors that control the production of plant wax $\delta^{13} \mathrm{C}$ values, relatively little is known about the processes that ultimately determine the integration and transport of plant waxes and their isotopic compositions to sedimentary archives. Freeman and Pancost (2014) caution about the simplifying assumption of equal integration of all plant sources within catchments, stressing the importance of understanding the factors and processes that

| control terrestrial organic matter delivery to sediments. In this section, the review focuses on the three dominant modes of plant wax transport: waxes attached to leaves, aeolian waxes, and erosion and deposition of soil-derived waxes. The relative contribution of plant waxes carried by each of these pathways will vary with the geologic setting and type of sedimentary record (i.e. terrestrial, lacustrine, or marine). Ultimately, the variability in climate and in vegetation composition underlies both spatial and temporal patterns in the $\delta^{13} \mathrm{C}$ values of terrestrial plant lipids both today and in the past, and

I understanding how these signals are transferred to and integrated in sediments is critical.

\subsubsection{Integration and transport of leaves and plant waxes to sediments}

Leaves are integrated in ecosystems and deposited in sediments (Burnham, 1989; Greenwood, 1991; Burnham, 1994; Ellis and Johnson, 2013). However, due to taphonomic processes, the species composition in a forest is not necessarily reflected in the forest litter and sediments. Leaves are

I transferred from biomass to sediments when they fall to the forest floor, creating autochthonous assemblages (i.e. swamps) or are transported by wind and water creating allochthonous assemblages (i.e.

I lakes, ponds, stream deposits; Greenwood, 1991). The composition of leaf litter in allochthonous assemblages tends to be swamped by leaves from the adjacent canopy (Burnham, 1989). In temperate forests, the leaf litter tends to be dominated by the most abundant tree species, but not necessarily in tropical forests (Brasell et al., 1980; Greenwood, 1991; Burnham et al., 1992; Ellis and Johnson, 2013). Trees with the largest basal area also tend to have greater representation in sediments than trees with smaller basal areas, despite having a greater number of stems within the forest stand (Ellis and Johnson, 2013). Within that context, leaf litter is likely biased to the top of the canopy due to higher biomass, production rate, higher photosynthetic rate and shorter leaf lifespan (Parker et al., 1989; Reich et al., 
1991; Wright and Cannon, 2001), which is supported by fossil assemblages (e.g., Graham et al., 2014).

| When leaves are transported by wind, smaller and lighter leaves tend to travel further than larger and heavier leaves (Spicer, 1981). Importantly, leaves entering lakes tend to be dominated by woody vegetation surrounding the lake (McQueen, 1969; Drake and Burrows, 1980; Spicer and Wolfe, 1987;

| Greenwood, 1991). If leaf wax transport to sediments were primarily of the leaf surface, then these taphonomic processes would provide a filter on which species' leaf waxes enter the sedimentary record.

I Surveys of lake sediments and vegetation suggest that leaf wax input from angiosperm trees may dominate the lacustrine sedimentary record, at least for $n$-alkanes (Cranwell et al., 1987; Sachse et al., 2006, 2012; Diefendorf et al., 2011; Tipple and Pagani, 2013). There is also an indication that leaf waxes from grasses are under-represented in the lacustrine sedimentary record due to differences in leaf wax production and transport between grasses and trees, which has important implications for reconstructing changes in $\mathrm{C}_{3}$ and $\mathrm{C}_{4}$ vegetation based on leaf wax $\delta^{13} \mathrm{C}$ (Seki et al., 2010; Garcin et al., 2014; Schwab et I al., 2015), but is highly dependent on leaf wax chain length. In contrast, plant wax $\delta^{13} \mathrm{C}$ values in marine sediments are sensitive to the relative abundance of both $\mathrm{C}_{3}$ tree/shrub and $\mathrm{C}_{4}$ grass/sedge vegetation (Collins et al., 2011; Vogts et al., 2012), perhaps because marine records integrate waxes over regional to continental scales via wind-blown dust and riverine networks.

Thus, some consideration of vegetation, through pollen, macrofossil, or phytolith analysis can further inform interpretation of sediment plant wax $\delta^{13} \mathrm{C}$ values. However, variable production, sourcing and dispersal can also bias records of each of these vegetation proxies (Prentice, 1985). Taphonomic effects, combined with plant wax production and carbon isotope differences among growth forms (grasses, trees, shrubs), major taxonomic groups (angiosperms and gymnosperms) and species can complicate the interpretation of sedimentary plant wax $\delta^{13} \mathrm{C}$ values, especially during transitions in vegetation and climate or when comparing among depositional environments.

\subsubsection{Aeolian sources of plant waxes}


I Plant waxes can either be ablated from the leaf surface by wind and other abiotic stressors, including rain, heat and UV radiation (Baker and Hunt, 1986; Simoneit et al., 1988; Shepherd and Wynne Griffiths, 2006) or adsorbed to smoke particles from biomass burning (Standley and Simoneit, 1987; Simoneit, 2002). These particulate waxes can be transported great distances by winds as aerosols or on dust surfaces (Simoneit, 1977; Simoneit et al., 1977; Duce and Gagosian, 1982; Simoneit and Mazurek, 1982; Bird et al., 1995; Huang et al., 2000). Plant wax aerosols can be deposited either via dry deposition, when particles fall out of the air, or by wet deposition, when aerosols and dusts are scrubbed from the air during precipitation events, the latter being quantitatively more important (Eichmann et al., 1979, 1980). In marine sediments, aeolian plant waxes can be the dominant source of sedimentary plant waxes, especially when riverine input is limited or nonexistent (Schefuß et al., 2003, 2004). In North America, many studies have identified African plant wax aerosols, documenting the great distances plant waxes travel (e.g. Huang et al., 2000). From spring to fall, the majority of aerosol plant waxes are sourced from local to regional scales and the composition reflects atmospheric mixing and advection of storm systems (Conte and Weber, 2002; Conte et al., 2003). During winter months in North America, plant wax aerosols are much lower in concentration and will reflect long distance transport (Meyers and Hites, 1982).

Meyers and Hites (1982) measured long chain $n$-alkanes and $n$-alkanoic acids in rain and snow to determine the importance of eolian plant waxes as contributors to sedimentary plant waxes in Lake Michigan. Importantly, they estimated that the maximum contribution of aerosol $n$-alkanes from rain and snow to sedimentary $n$-alkanes was $15 \%$. They also found that the flux of $n$-alkanoic acids was much

| lower than $n$-alkanes by a factor of ca.10. They argue that eolian sources of plant waxes are important in lakes with low productivity and low terrigenous input, but likely have a minimal influence on lakes with high productivity and high sedimentation. Therefore, in sites with a high terrestrial input, the locally derived plant waxes would likely swamp the eolian-sourced plant waxes.

\subsubsection{Plant wax reworking and temporal resolution}


Riverine transport of reworked terrestrial plant waxes is another major pathway for delivery of waxes and I other terrestrial biomarkers to marine and lake sediments. Rivers transport ca. $0.4 \mathrm{Gt} / \mathrm{yr}$ of dissolved and particulate organic carbon (OC) to the marine realm (Hedges and Oades, 1997) with a preservation efficiency in sediments of ca. 20-40\% (Blair and Aller, 2012). Of this total riverine OC flux, the particulate flux is comprised of ca. $0.16 \mathrm{Gt} / \mathrm{yr}$ biogenic and $0.04 \mathrm{Gt} / \mathrm{yr}$ petrogenic carbon (Galy et al., 2015). Total riverine transported OC represents a mixture of sources, but is generally dominated by an input from soil (Hedges and Oades, 1997). Eolian transport of OC is estimated to be $<0.1 \mathrm{Gt} / \mathrm{yr}$ and may be a more significant source of terrestrial OC in the open oceans (Hedges and Oades, 1997).

The source attribution, transport and composition of fluvially transported plant waxes may be influenced by multiple factors, including catchment vegetation cover, seasonality, degradation, and particle sorting and trapping in river sediments (Pancost and Boot, 2004). In tropical and subtropical settings, the stable isotopic composition of plant waxes in-transit in soils and riverine particulate organic matter (POM) reflect $\delta \mathrm{D}$ gradients in precipitation and elevation (Galy and Eglinton, 2011; Ponton et al., 2014). The $\delta \mathrm{D}$ composition of $n-\mathrm{C}_{28}$ alkanoic acid in riverine POM reflects the average upstream catchment area at each | successive point along an elevation gradient in a tributary network to the Amazon (Ponton et al., 2014). In contrast, in central Madagascar, the $\delta^{13} \mathrm{C}$ composition of riverine $\mathrm{OC}$ is biased toward riparian $\mathrm{C}_{3}$ plants despite the catchment being dominated by $\mathrm{C}_{4}$ grasslands (Marwick et al., 2014). The isotopic composition of riverine $\mathrm{OC}$ and terrestrial plant biomarkers can also change between wet and dry seasons, reflecting different fluvial sourcing or OC mobilization mechanisms during wet and dry flow regimes (Marwick et al., 2014; Ponton et al., 2014). Further, the concentration and relative abundance of terrestrial plant $n$ alcohols and $n$-alkanoic acids in fluvial suspended sediments fluctuate with seasonal change in discharge from the Congo River, while those of the $n$-alkanes are more stable (Hemingway et al., 2016). These studies highlight the importance of accounting for variation in the seasonal or storm-driven fluxes and resulting composition of terrestrial plant biomarkers sourced by fluvial networks, especially in sedimentary records that span periods of hydrologic change. 
OC transported by rivers generally comprises one or more carbon pools that range in age from modern (fresh biomass production), to pre-aged (through some residence time in soil) and ancient (eroded from sedimentary rocks; Hedges and Oades, 1997; Blair et al., 2003). Each of these pools may also have distinct $\delta^{13} \mathrm{C}$ values, thereby influencing both the age and the carbon isotopic record of sedimentary bulk OC (Blair et al., 2003; Bataille et al., 2013). The relative contribution of modern, pre-aged and ancient OC delivered to marine sediments can be controlled not only by ecosystem productivity and source reservoir concentration, but also by the geology and morphology of different drainage basins. Based on the $\delta^{13} \mathrm{C}$ and ${ }^{14} \mathrm{C}$ composition of $\mathrm{OC}$ in a fluvial/marine system on the coast of California, Blair et al. (2003) suggested that tectonically active basins have shorter residence times and deliver greater portions (up to $50 \%$ ) of ancient carbon to marine sediments than at passive margins. This was supported by a global compilation of ${ }^{14} \mathrm{C}$ ages of riverine particulate $\mathrm{OC}$ that found that low-relief passive margins and corresponding rivers with smaller suspended load (i.e. less efficient weathering) delivered a greater portion of modern OC (Blair and Aller, 2012).

While basin geology and morphology may be important controls on the age and $\delta^{13} \mathrm{C}$ composition of I riverine transported OC, the same controls may not pertain for terrestrial plant biomarkers because lipids make up $<1 \%$ of TOC (de Leeuw et al., 1995; Blair and Aller, 2012). Therefore, it is likely that there are discrepancies between the age/source of bulk OC and specific biomarkers. With the advent of compoundspecific radiocarbon analysis (CSRA; Eglinton et al., 1996) it became possible to directly measure the ${ }^{14} \mathrm{C}$ age of biomarkers, including terrestrial plant waxes, in source material, during riverine transport and in associated sediments. Mixing models of the $\delta^{13} \mathrm{C}$ and $\Delta{ }^{14} \mathrm{C}$ composition of waxes can be used to determine plant wax residence times and fractional contributions of modern (biomass), pre-aged (soil), I and ancient (petrogenic) wax sources. Most studies have applied CSRA to fluvial/marine systems, although several recent studies have investigated the source and age offsets of terrestrial plant waxes in lake sediments and in soils (see below).

| For marine sediments, the continental residence time of terrestrial (i.e. long chain, $>n-\mathrm{C}_{25}$ ) plant waxes (including $n$-alkanes and $n$-alkanoic acids) ranges from < $100 \mathrm{yr}$ (Pearson and Eglinton, 2000; Pearson et 
al., 2001) to more than ca. 10,000 yr (Eglinton et al., 1997; Drenzek et al., 2007). This wide range of residence times is likely controlled by complex factors, but it is apparent that they vary among sites as a function of climate, geology and morphology. Plant wax transport pathways and the composition of source reservoirs within a catchment can affect sedimentary wax age. For instance, long chain $n$-alkanes in sediments from the Black Sea, where OC is largely transported by rivers, had ${ }^{14} \mathrm{C}$ age values of 500-1,130 yr BP, whereas sediments from the Arabian Sea, which has a significant aeolian input, had $n$ $\mathrm{C}_{29}$ alkane age of 7,200 yr BP, possibly due to wind erosion of pre-aged waxes from a source reservoir of desiccated lake sediment (Eglinton et al., 1997). In a study of Congo River basin sediments, a hydrologic control on the reworking of leaf waxes was identified (Schefuß et al., 2016). The authors used ${ }^{14} \mathrm{C}$ ages of $n$-alkanes, in combination with methanogen biomarkers as evidence for wetlands, to identify changes in | the storage of plant waxes within the Congo Basin. Schefuß et al. (2016) highlight that, even in flat tropical basins, plant waxes can be stored for thousands of years before being remobilized, due to hydrological change, into marine depositional environments.

| The shortest terrestrial $n$-alkane residence time $(75 \mathrm{yr})$ was observed in the Santa Monica Basin, where an estimated $>80 \%$ of sedimentary waxes were derived from modern plants, with remaining fractions derived from shales and petroleum (Pearson and Eglinton, 2000). This is consistent with the estimated average residence time of carbon in the upper $1 \mathrm{~m}$ of soil humus ( $80 \mathrm{yr}$; Hedges and Oades, 1997). A later

I study of sediments in the same region determined significantly longer terrestrial residence times for $n$ - $\mathrm{C}_{28}$ alkanoic acid, from 1,200 yr in the Santa Barbara Basin to 750-1,090 yr in the Santa Monica Basin

I (Mollenhauer and Eglinton, 2007). In contrast, Kusch et al. (2010) observed younger $n$-alkanoic acid age relative to $n$-alkanes in Black Sea sediments, either due to greater recalcitrance of $n$-alkanes or their potential 'contamination' with ancient petrogenic sources. Variable ${ }^{14} \mathrm{C}$ ages among terrestrial biomarkers and among $n$-alkanes and $n$-alkanoic acids in the same sediments (Eglinton et al., 1997; Smittenberg et

I al., 2004; Feng et al., 2013) are a further indication that the sourcing, transport and preservation of biomarker records is variable among depositional settings and perhaps among lipid compound classes. 
The longest terrestrial plant wax residence times have been observed at high latitudes, ranging from 4,000-5,500 yr for soil-derived sedimentary $n$-alkanes from the Saanich Inlet of the Pacific Northwest (Smittenberg et al., 2004) up to > ca. 10,000 yr for Arctic marine sediments (Drenzek et al., 2007). Protracted storage of total OC (TOC) in permafrost results in TOC in Arctic surface sediments with ages of 7,000-16,750 yr BP (Goñi et al., 2005). Likewise, sedimentary plant wax ages correlated with percent cover of discontinuous permafrost in a transect of Eurasian Arctic rivers, likely because discontinuous permafrost facilitates mobilization of deep, pre-aged waxes in permafrost (Feng et al., 2013).

Additionally, evidence from sub-Arctic Scandinavia suggests that there may be selective preservation of pre-aged, mineral-bound lipid pools derived from permafrost relative to younger, more degradable lipids from upper soil layers and peat (Vonk et al., 2010). Therefore, climate can influence the source reservoir composition, extent of pre-aging and resulting ages of plant waxes and other terrestrial biomarkers in marine sediments.

In the Eel River basin in coastal northern California, insights from CSRA suggest that, even in this tectonically active margin where bulk TOC export is thought to be rapid and dominated (ca. 50\%) by shale-derived ancient carbon (Blair et al., 2003), n-alkanoic acids have residence times of several thousand years. Therefore, pre-aged lipids may contribute to sedimentary carbon ages to a greater extent than previously estimated (Drenzek et al., 2009). Similarly, (Galy and Eglinton, 2011) found evidence that different pools of $\mathrm{OC}$ have significantly different residence times in the Ganges-Bramaputra river system. While the age of $n$-alkanoic acids ranged from 50-1,300 yr, bulk OC was $>15,000 \mathrm{yr}$ on average, suggesting that up to $20 \%$ of the $\mathrm{OC}$ transported by the river system is made up of a much older, more refractory pool of carbon.

Several studies have applied CSRA to examine the residence times and transport mechanisms of terrestrial plant waxes within lake catchments. The observed age offsets of plant waxes in lake sediments are generally smaller than for marine sediments; however the former varies among depositional settings and may be sensitive to the extent of soil erosion and transport to a basin. For instance, in a karstic sinkhole pond in Hawaii, the ${ }^{14} \mathrm{C}$ ages of $n-\mathrm{C}_{27}-n-\mathrm{C}_{33}$ alkanes in sediments were not significantly offset 
from the ages of macrofossils (Uchikawa et al., 2008). It is important to note that this is a relatively small $\left(0.005 \mathrm{~km}^{2}\right)$ and hydrologically closed basin fed by groundwater and precipitation. Further, the catchment has poor soil development and is in a low gradient coastal plain. Thus, the sedimentary waxes are likely transported as aerosols or directly as leaves or leaf litter, which would result in minimal terrestrial residence time prior to deposition.

In another lake with no surface water input in Switzerland, terrestrially derived $n$ - $\mathrm{C}_{27}-n$ - $\mathrm{C}_{31}$ alkanes ranged from 120 to 1,000 (mean 396) ${ }^{14} \mathrm{C}$ yr older than sediments deposited prior to 3,100 cal yr BP (Gierga et al., 2016). However, in younger (400 cal yr BP) sediments, the age offset of waxes relative to sediments increased to 3,570 and 7,390 ${ }^{14} \mathrm{C}$ yr BP. An increased contribution of pre-aged plant waxes in recent sediments may reflect increased erosion of soils in the drainage basin following intensified forest clearing and agricultural development in the area. Thus, erosion and surface runoff may be important

| factors in mobilizing pre-aged waxes that would otherwise be retained on the landscape. In arid settings, eolian transport of reworked dunes and dust may be an important source of significantly pre-aged $n$ alkanes in hypersaline lakes (Bray et al., 2014).

In tropical settings, long chain $n-\mathrm{C}_{26}-n-\mathrm{C}_{32}$ alkanoic acids in core top sediments from four karstic Mexican and Central American lakes had ${ }^{14} \mathrm{C}$ age from 20-520 yr BP (Douglas et al., 2014). The oldest waxes were found in larger lake catchments and at sites with lower mean annual precipitation. Soils within the largest catchment contained $n$-alkanoic acids that had increasing ${ }^{14} \mathrm{C}$ age with depth, suggesting that sedimentary lipids are sourced from older soils. In this lake, $n$-alkanoic acids showed an increasing age offset (up to 1,200 yr) relative to sediments at greater depth.

These studies suggest that the residence time of terrestrial plant waxes in lake sediments may be linked to I catchment and lake size, soil development, landscape erosion/stabilization, surface water input, hydrologic controls, and aridity. Further work is needed to test these and other basin-specific controls on the residence times of terrestrial plant biomarkers in lacustrine sediments in order to extract more accurate climate information from plant waxes in terrestrial records. Testing biomarker-specific age-depth offsets 
and lag times may be especially important when using plant wax isotopes as climate/vegetation proxies as | they may have lower resolution than other proxies (e.g. authigenic carbonate).

In contrast to marine and lake systems, CSRA analysis of $n$-alkanes and $n$-alkanoic acids from a Quaternary loess-paleosol sequence found good age agreement between plant waxes and corresponding stratigraphic horizons (Häggi et al., 2014), suggesting negligible age offsets for plant waxes in paleosols. This information is helpful for paleoenvironmental reconstruction for the Miocene through the late Quaternary (Freeman and Colarusso, 2001; Zech et al., 2012; Magill et al., 2013; Uno et al., 2016a, b). However, it is important to be aware of possible OC reworking when paleosols are formed on alluvial deposits (Baczynski et al., 2013, 2016).

\subsubsection{Plant wax alteration and diagenetic fate}

In lacustrine and marine water columns, $n$-alkanes, $n$-alkanoic acids and $n$-alkanols are refractory and are preferentially concentrated relative to other lipids (e.g. Meyers and Ishiwatari, 1993; Wakeham et al., 1997; Hoefs et al., 2002; Sinninghe Damsté et al., 2002; Prahl et al., 2003). After plant waxes are buried | in lacustrine and marine sediments, alteration occurs rapidly. For example, studies of recent lake sediments suggest that alteration occurs in less than a few hundred years (Meyers et al., 1980; Cranwell, 1981). Once these compounds make it through the most active zone of degradation within the sediment column, they are relatively resistant to microbial degradation (e.g. Meyers and Ishiwatari, 1993; Wakeham et al., 1997). Of the $n$-alkyl lipids, $n$-alkanes are more resistant to degradation than the $n$ alkanoic acids and $n$-alkanols (Cranwell, 1981). It is important to note that almost all field-based studies must assume that the source of plant waxes remains constant through time. This poses a challenge for identifying the effects of alteration and diagenesis as source variation may also be important in explaining downcore plant wax variation. Thus, alteration may not be the only factor causing changes in $n$-alkyl lipids (Powell and McKirdy, 1973). Nevertheless, microbial oxidation of $n$-alkanes is evident from the presence of $n$-alkan-2-ones in lacustrine sediments. In two different studies, chain length distributions of

| $n$-alkan-2-ones matched those of co-occurring $n$-alkanes, indicating that microbial oxidation had occurred (Cranwell et al., 1987; Rieley et al., 1991). In addition to oxidation, it is likely that some plant waxes are 
incorporated into a bound fraction (Cranwell, 1981). Overall, the diagenetic alteration and preservation of plant waxes is determined largely by sediment composition, oxygen exposure (Hartnett et al., 1998), and burial (Meyers and Ishiwatari, 1993), as is also true for other biomarkers and bulk OC (Powell and McKirdy, 1973; Hedges and Prahl, 1993; Hedges and Oades, 1997; Wakeham et al., 1997). In marine settings, terrestrial biomarkers, such as $n$-alkanes, will be preferentially preserved relative to marine | biomarkers, such as alkenones (e.g. Hoefs et al., 2002; Sinninghe Damsté et al., 2002; Prahl et al., 2003).

I For the plant waxes preserved following deposition, burial and early diagenesis, additional changes occur as sediments are heated. During heating, sedimentary plant waxes undergo changes in composition and concentration. For immature sediments, $n$-alkanoic acids and $n$-alkanols are polymerized to insoluble macromolecules through diagenetic alteration. Evidence for this polymerization and formation of kerogen comes from extensive use of confined and hydrous pyrolysis experiments using fresh leaf or arthropod tissue (Stankiewicz et al., 2000; Gupta et al., 2007a; Gupta, 2014; Diefendorf et al., 2015c) and from observations made on fossils (e.g., Mösle et al., 1997, 1998). For immature sediments and rocks, $n$ alkanes appear to be rather immobile. This was evidenced by molecular studies of fossil leaf cuticle and co-occurring sediment matrix from the Miocene Clarkia Formation (Huang et al., 1995; Logan et al., I 1995). In these studies, $n$-alkanes in the cuticle were distinct from the sediment matrix and it was concluded that $n$-alkanes were not migrating into the sediment matrix. With increasing maturity (oil generation), $n$-alkanes, including both short and long chain, are produced. They are likely generated from polymerized macromolecules (such as $n$-alkanoic acids, $n$-alkanols, cutan and cutin) and kerogens that were preserved during fossilization of leaves (Collister et al., 1994a; Eglinton, 1994; Finch and Freeman, | 2001; Gupta et al., 2006, 2007a,b; Gupta, 2014). As maturity progressively increases, the odd/even preference is lost and the average chain length decreases (e.g., Bray and Evans, 1961; Brooks and Smith, 1967). Because the diagenetic alteration of $n$-alkyl lipids results in compositional changes, it becomes increasingly challenging to extract information from chain length distributions with increasing maturity | and the possibility of $n$-alkyl lipids generated from non-plant wax sources increases (e.g. Tegelaar et al., 1989). 
Despite significant loss of plant waxes following burial and subsequent diagenetic alteration, their carbon isotopic composition remains unaltered. For example, in a 23 yr litter bag field experiment with Calluna vulgaris (heather), Huang et al. (1997) found that long chain $n$-alkane $\delta^{13} \mathrm{C}$ values were unchanged despite a $90 \%$ loss in $n$-alkanes. Other studies have suggested that $n$-alkanes are altered (e.g. Nguyen Tu et al., 2004a; Chikaraishi and Naraoka, 2006; Nguyen Tu et al., 2011), but contributions of $n$-alkanes from

I other sources often can not be ruled out or the starting composition is not well constrained. These conflicting results highlight the challenges of field-based studies due to possible reworking and multiple

I sources of $n$-alkanes within soils (e.g. Lichtfouse, 2011). Upon heating and increasing maturity, $n$-alkane $\delta^{13} \mathrm{C}$ values appear to not be altered up to the pre-oil generation window. This was determined with hydrous pyrolysis experiments using fresh leaves from Acer rubrum (red maple), Platanus occidentalis

| (American sycamore), Pinus sylvestris (Scots pine) and Taxodium distichum (bald cypress) at various temperatures (Diefendorf et al., 2015c). In that study, changes in long chain $n$-alkane $\delta^{13} \mathrm{C}$ values were not

| observed until hydrous pyrolysis temperatures increased to $250{ }^{\circ} \mathrm{C}$ and above. Above that temperature, the magnitude and direction of the $\delta^{13} \mathrm{C}$ change was variable among species and chain lengths, but generally was $\leq 2 \%$. The differences among species are curious and suggest that other $n$-alkyl lipids are converted

| to $n$-alkanes, thereby influencing their isotopic composition. Overall, the small changes in $\delta^{13} \mathrm{C}$ values are consistent with other studies that have identified progressive alteration of $n$-alkane $\delta^{13} \mathrm{C}$ values with increasing maturity, with the greatest changes occurring in the mid to upper oil window (Bjorøy et al., 1992; Clayton and Bjorøy, 1994). For oils, there appears to be no evidence for isotopic fractionation for

| long chain $n$-alkanes $\left(\geq \mathrm{C}_{19}\right)$ during biodegradation, even for oils with extreme biodegradation (Sun et al., 2005). Thus, for geologic studies focused on sediments and rocks with immature to early oil window | maturities, long chain $n$-alkane $\delta^{13} \mathrm{C}$ values should be unaltered or only slightly altered (c. $1 \%$ ).

\section{Paleorecord applications}

I Interpreting sedimentary carbon isotope values of bulk OM and plant waxes as signals of paleoclimate, paleovegetation, or carbon cycle changes is complicated by competing influences of climate, vegetation, and atmospheric $\delta^{13} \mathrm{C}$. The interpretation also depends, at least in part, on the depositional environment in 
which plant waxes are preserved. In records from lakes, ponds, swamps and soils, plant waxes are likely sourced from a local signal. However, the spatial integration of plant waxes reflected in that local environment will depend on how waxes are transported from plant to sediment (Section 3.4.1) and if

| waxes are inherited from distal eolian sources (Section 3.4.2). In records from marine sediments, plant waxes will likely be integrated from a large spatial extent and represent multiple biomes and climates.

| Thus comparing $\delta^{13} \mathrm{C}$ values through time, across space and between terrestrial and marine sediments is difficult without additional information. By utilizing the large body of information about the factors that influence plant carbon isotopes, and by combining with independent proxies, it is now possible to reduce

uncertainty and improve the interpretations made from plant carbon isotopes preserved in the sedimentary record. This section has been divided into three parts, each focusing on the most common interpretations made from plant $\delta^{13} \mathrm{C}$ values.

\subsection{Plant carbon isotopes as water indicators}

Interpreting changes in $\mathrm{C}_{3}$ plant $\delta^{13} \mathrm{C}$ values as water availability or as precipitation indicators has become I common in the literature. As discussed above, water availability has a strong control on $\mathrm{C}_{3}$ plants and its influence on their stomatal conductance, which in turn influences $C_{i}$, and thus plant fractionation during I photosynthesis. However, plant type, vegetation, photosynthetic pathway and many other factors also influence $C_{i}$ and therefore modify $\Delta_{\text {leaf. }}$ This has important consequences for interpreting plant $\delta^{13} \mathrm{C}$ values. For plant $\delta^{13} \mathrm{C}$ values to be useful as a proxy for water availability, competing factors must also be accounted for when interpreting sedimentary $\delta^{13} \mathrm{C}$ values. For times and regions where the researcher is confident that $\mathrm{C}_{4}$ plants are absent, extracting a water signal from plant $\delta^{13} \mathrm{C}$ values can be done if vegetation and $\delta^{13} \mathrm{C}_{\text {atm }}$ are constrained. Paleovegetation can be identified using pollen and macrofossils, | ideally from published studies, or possibly estimated from global biome models (e.g. Kaplan et al., 2003; Prentice et al., 2011a). For studies that utilize plant waxes, additional precautions can be made by knowing which conifer families are present in a geographic region of interest and utilizing $n$-alkane chain I lengths that are most likely angiosperm or conifer in origin. In lithologies with good OM preservation, 
plant terpenoids can be utilized as taxon specific biomarkers and can be compared with $n$-alkane $\delta^{13} \mathrm{C}$ values (e.g. Schouten et al., 2007).

When interpreting plant $\delta^{13} \mathrm{C}$ values through time intervals when plant communities remain constant, then plant $\delta^{13} \mathrm{C}$ values are likely to represent water availability, at least qualitatively. Kohn (2010) provides a

I paleoprecipitation proxy based on observed change in plant $\delta^{13} \mathrm{C}$ values with change in mean annual precipitation. If vegetation is constant, then this approach may prove useful given that the $\delta^{13} \mathrm{C}$ values of individual species are tightly correlated with water availability, although different species have unique relationships (e.g. Prentice et al., 2011b). Given the wide variability in plant $\delta^{13} \mathrm{C}$ values at a given site and unique species-level relationships between $\Delta_{\text {leaf }}$ and water availability, the uncertainty in precipitation estimates based on plant $\delta^{13} \mathrm{C}$ values is likely to be large, especially if the plant community changes through time (Freeman et al., 2011). Depending on the application and required uncertainty, the approach may nevertheless prove useful (Cernusak et al., 2013), but will require constraining uncertainty in paleoprecipitation estimates.

Recently, Sikes et al. (2013) used a multiproxy approach to identify changes in aridity during the most recent deglaciation in New Zealand from maar sediments. By combining plant wax $\delta^{13} \mathrm{C}$ values with pollen, biomarkers for fire, and sea surface temperature, they were able to identify a shift from cold and dry conditions during the Last Glacial Maximum to a seasonally warm and wet climate. This interpretation was based on several negative shifts in plant wax $\delta^{13} \mathrm{C}$ values. By using pollen and other indicators, the authors were able to rule out other possible controls on the plant wax $\delta^{13} \mathrm{C}$ values. In a similar study off the coast of Africa, Hoetzel et al. (2013) were able to combine pollen data with plant I wax $\delta^{13} \mathrm{C}$ values to better constrain the timing of the rise of $\mathrm{C}_{4}$ grasses in a context of increasing fire, as evidenced from charcoal grains.

\subsection{Plant carbon isotopes as vegetation indicators}


The use of plant $\delta^{13} \mathrm{C}$ values as proxies for paleovegetation is commonplace for interpreting changes in $\mathrm{C}_{3}$ and $\mathrm{C}_{4}$ vegetation through time and across space (France-Lanord and Derry, 1994; Freeman and Colarusso, 2001; Tipple and Pagani, 2010; Feakins et al., 2013; Uno et al., 2016a,b). $\delta^{13} \mathrm{C}$ values of plants have also been utilized to identify sources of $\mathrm{OM}$ as conifer derived or angiosperm derived for time periods prior to the rise of $\mathrm{C}_{4}$ plants. The approach works best at single localities where differences in water availability are minimal, and is often used on specific substrates such as wood, peat and resins (e.g. Murray et al., 1998; Bechtel et al., 2002, 2008).

Utilizing plant $\delta^{13} \mathrm{C}$ values as proxies for $\mathrm{C}_{3} / \mathrm{C}_{4}$ vegetation relies on the observation that $\mathrm{C}_{4}$ plants are I mostly grass species, so changes in $\delta^{13} \mathrm{C}$ values should be a good indicator of the relative abundance of forests to grasslands through time. However, a significant challenge with this approach is the fact that many grasses use the $\mathrm{C}_{3}$ pathway. Additionally, ecosystems do not transition linearly from $\mathrm{C}_{3}$ plant dominated to $\mathrm{C}_{4}$ plant dominated, but rather reflect a patchy continuum of ecosystems from closed canopy forests to open $\mathrm{C}_{4}$ grasslands, each with a unique range of $\delta^{13} \mathrm{C}$ values, rather than a continuous gradient (Freeman and Pancost, 2014). For example, forests are composed of trees, shrubs and herbaceous plants, and can be considered $\mathrm{C}_{3}$. Because forests represent a combination of species, each with unique $\Delta_{\text {leaf }}$ values, a large range in $\delta^{13} \mathrm{C}$ values is expected (up to $8 \%$ in tropical rainforests; Bonal et al., 2000) that cannot be characterized by a single value. As forests open up and the proportion of woody plants decreases, grasslands emerge. The proportion of $\mathrm{C}_{3}$ and $\mathrm{C}_{4}$ vegetation within grasslands varies and the controls on the vegetation composition are complex, but appear to be related to water availability, as well I as other factors (e.g. Edwards et al., 2010; Edwards and Smith, 2010). To address these complexities in modeling vegetation change from plant $\delta^{13} \mathrm{C}$ values, Cerling et al. (2011) and Magill et al. (2013) have suggested using ecosystem classifications (i.e. forest, woodland, grassland) and defining appropriate ranges of $\delta^{13} \mathrm{C}$ values for each ecosystem type (Fig. 10). This approach is elegant in that it acknowledges the complexities of vegetation and climate among ecosystems, although more information may be extracted than type alone. For example, Ladd et al. (2014) used a multivariate approach that allows the leaf area index to be constrained, although the approach may be challenging for paleo studies where 
several of the input variables would be difficult to constrain (i.e. temperature, precipitation, seasonality, etc.).

Many substrates preserve a signature of plant $\delta^{13} \mathrm{C}$ values and thus $\mathrm{C}_{3} / \mathrm{C}_{4}$ vegetation patterns. These

| include fossil cuticles, soil OM, phytoliths, pedogenic carbonate nodules, herbivore tooth enamel, pollen, and plant waxes. Each of these substrates has its own inherent challenges and caveats for extracting a | primary vegetation signal. For example, $\delta^{13} \mathrm{C}$ values of soil are shifted to higher values (by up to $6 \%$ ) during pedogenesis (Wynn et al., 2005; Wynn, 2007). For plant waxes, challenges arise because different

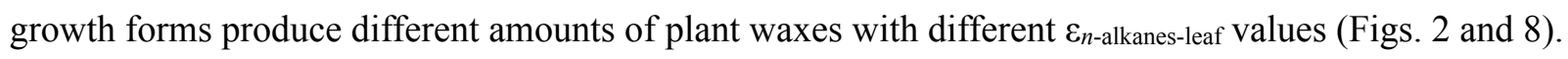
Garcin et al. (2014) approached this problem by taking into account the $n$-alkane concentration differences among plant functional types, along with their $\delta^{13} \mathrm{C}$ values, for different chain lengths and latitudes (Fig. 11). By combining that information into a model, the authors were able to estimate $\% \mathrm{C}_{4}$ | vegetation. This approach includes an estimate of uncertainty, a significant advancement over previous

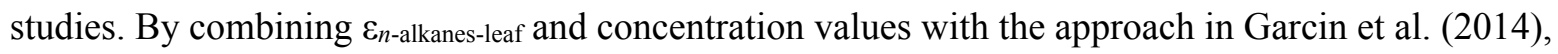
ecosystem types could be defined (Cerling et al., 2011; Magill et al., 2013) to avoid the challenges of

I single end-member values, and therefore the method should reduce uncertainty in ecosystem characterization. Regardless of the approach used, it is critical to evaluate $n$-alkane $\delta^{13} \mathrm{C}$ shifts for different chain lengths. For example, Uno et al. (2016a) were able to document a shift from $\mathrm{C}_{3}$ to $\mathrm{C}_{4}$ vegetation during the Neogene by carefully examining the increases in concentration and $\delta^{13} \mathrm{C}$ values of $n-\mathrm{C}_{33}$ and $n-\mathrm{C}_{35}$.

The use of plant wax $\delta^{13} \mathrm{C}$ values as a screening tool to identify possible bias in plant wax $\delta \mathrm{D}$ interpretations because of changes in the proportion of $\mathrm{C}_{3}$ and $\mathrm{C}_{4}$ plants, and associated differences in hydrogen isotopic fractionation may prove useful for hydroclimate reconstruction (Collins et al., 2013; Vogts et al., 2016).

\subsection{Plant carbon isotopes as recorders of carbon isotope excursions}


| The carbon isotopic composition of plants and plant biomarkers is linked to atmospheric $\delta^{13} \mathrm{C}$. Therefore, plant carbon isotopes can provide a past record of carbon cycle changes and can be especially useful for periods when the marine record is absent or is not in isotopic equilibrium with the atmosphere (Hayes, 1993; Koch, 1998; Hayes et al., 1999; Kump and Arthur, 1999; Bowen, 2013). However, the key to reconstructing past changes in the carbon cycle from plant $\delta^{13} \mathrm{C}$ values is accounting for the fractionation between plants and atmospheric $\mathrm{CO}_{2}$. For $\mathrm{C}_{4}$ plants, fractionation is relatively easy to predict as their $\Delta_{\text {leaf }}$ values are not sensitive to water and the total measured range is rather small (Fig. 7). Thus, predicting $\delta^{13} \mathrm{C}_{\text {atm }}$ from $\mathrm{C}_{4}$ plants is rather simple. In contrast, the many factors that affect $\mathrm{C}_{3}$ plant $\Delta_{\text {leaf }}$ values make predicting $\delta^{13} \mathrm{C}_{\text {atm }}$ much more complicated, as additional information is necessary to constrain $\Delta_{\text {leaf }}$ values | (e.g. Diefendorf et al., 2010, 2015a).

In order to predict $\delta^{13} C_{\text {atm }}$ values from $C_{3}$ plants, Diefendorf et al. (2010) suggested an approach that takes into account the various controls on both $\Delta_{\text {leaf }}$ and $\varepsilon_{\text {lipid. }}$ In that study, the authors utilized paleoprecipitation estimates from fossil leaves to correct for the influence of precipitation on $\Delta_{\text {leaf }}$ with modern calibrations (Diefendorf et al., 2010; Kohn, 2010). For other studies, water availability could be constrained with other paleoprecipitation proxies or by limiting sampling to wet depositional environments. In the Diefendorf et al. (2010) study, vegetation was constrained again with fossil leaves to inform the $\Delta_{\text {leaf }}$ calibration and to identify which $\varepsilon_{\text {lipid }}$ values to use. In this type of approach, it is critical to make some constraints on vegetation and then to make informed decisions about which plant biomarkers or $n$-alkane chain lengths to use. Based on the evidence at the time, Diefendorf et al. (2010) assumed an equal production of $n$-alkanes between conifers and angiosperms for $n-\mathrm{C}_{31}$ alkane. However, based on more recent studies (Diefendorf et al., 2011, 2015b; Bush and McInerney, 2013), we now know that many conifers produce a low concentration of $n$-alkanes vs. co-occurring angiosperms, and can thus be ignored in many, but not all, ecosystems.

A significant challenge with the approach above, or any similar approach, is making sure that modern calibration data, for $\Delta_{\text {leaf }}$ and $\varepsilon_{\text {lipid, }}$ are appropriate and do not overestimate the true range in values for a 
given ecosystem, thus leading to an overestimation of calculated uncertainty for past $\delta^{13} \mathrm{C}_{\mathrm{atm}}$. As indicated in the previous sections, there is a wide range of biomarker concentration (Fig. 2), $\Delta_{\text {leaf }}$ (Fig. 6) and $\varepsilon_{\text {lipid }}$ (Fig. 8) among species and growth forms. Determining how this species level information is integrated and averaged in the sedimentary record is unclear and presents a significant gap for the community.

The carbon isotope excursion (CIE) at the onset of the Paleocene-Eocene Thermal Maximum (PETM) presents one of the best examples of a global carbon cycle perturbation that is recorded by plant $\delta^{13} \mathrm{C}$ values. Measurements of the PETM CIE from plant lipids varied worldwide among 16 sites with values

| ranging from -7.6 to $-2.8 \%$ (McInerney and Wing, 2011). Much of the variability might be explained by concomitant changes in water availability and vegetation (Wing et al., 2009; McInerney and Wing, 2011), but other factors such as sampling resolution, time averaging and reworking of $n$-alkanes must also be important. To date, only a limited number of studies have been able to investigate and/or control these other factors when estimating the CIE (Bowen et al., 2004; Pagani et al., 2006; Schouten et al., 2007; Handley et al., 2008; Diefendorf et al., 2010; Tipple et al., 2011; Baczynski et al., 2013, 2016; Krishnan et al., 2015; Schoon et al., 2015) . These studies highlight the importance of having independent indicators of climate and vegetation change and also highlight the importance of having many records for a single carbon cycle perturbation. Reconciling plant biomarker-based CIEs is important for understanding the PETM, but equally important for providing insights into understanding how plants record changes in $\delta^{13} \mathrm{C}_{\mathrm{atm}}$. By making careful consideration of the factors that influence sedimentary biomarker $\delta^{13} \mathrm{C}$ values, more certain interpretations of plant $\delta^{13} \mathrm{C}$ values can be made.

\section{Conclusions}

Since the first publications reporting plant waxes (e.g. Eglinton et al., 1962; Eglinton and Hamilton, 1963, 1967), the number of studies utilizing sedimentary plant waxes has skyrocketed. Indeed, plant biomarkers, including plant waxes, and their carbon isotopes provide records of carbon cycling, paleovegetation and paleoclimate. Much progress has been made to understand what controls biomarker concentration and ${ }^{13} \mathrm{C}$ fractionation during photosynthesis and lipid biosynthesis in modern plants. This has improved our ability to interpret sedimentary biomarkers. However, it is clear from these modern 
| studies that interpreting a signal from sedimentary biomarker $\delta^{13} \mathrm{C}$ values, without controlling additional factors that influence plant $\delta^{13} \mathrm{C}$, will be problematic. If competing factors are constrained, then it is possible to extract the most information possible from the geologic record, while also reducing uncertainty in these interpretations. Below we summarize our knowledge on plant waxes and list current gaps and future directions.

\section{| 5.1. Summary Points}

- Plant waxes and their carbon isotopes provide records of past carbon cycling, paleovegetation, and paleoclimate. Much progress has been made to understand controls on plant wax

| concentration and ${ }^{13} \mathrm{C}$ fractionation in modern plants. Insights from these modern studies demonstrate that interpreting sedimentary biomarker $\delta^{13} \mathrm{C}$ values necessitates constraining factors that influence plant $\delta^{13} \mathrm{C}$ values. These include the $\delta^{13} \mathrm{C}$ composition of past atmospheric $\mathrm{CO}_{2}$, changes in plant community and associated fractionation, and past hydrological shifts that influence ${ }^{13} \mathrm{C}$ fractionation during photosynthesis.

- Distinct plant wax abundance, chain length distribution and ${ }^{13} \mathrm{C}$ fractionation among species, growth habits and physiology may influence plant wax signals in sediments. Past source vegetation and growth conditions may be characterized using additional vegetation proxies, plant biomarkers and sediment properties.

- Differences in ${ }^{13} \mathrm{C}$ fractionation among $\mathrm{C}_{3}$ and $\mathrm{C}_{4}$ vegetation are encoded in plant wax $\delta^{13} \mathrm{C}$ values, providing a tool for interpreting past ecological shifts and the rise of $\mathrm{C}_{4}$ plants. Careful determination of the plant wax $\delta^{13} \mathrm{C}$ values and chain(s) of interest are needed when ascribing changes in the $\mathrm{C}_{3}$ and $\mathrm{C}_{4}$ plant community. A promising way to address the challenges inherent in single end-member values is to characterize ${ }^{13} \mathrm{C}$ fractionation diagnostic for a range of ecosystems.

- When using sedimentary plant wax and other biomarkers, it is important to consider the sourcing, transport and preservation in each specific depositional system (e.g. lacustrine, marine, soil) and climate/biome (e.g. tropical, temperate, boreal). The various processes controlling the integration of waxes into sediments will impact the abundance, isotope composition and sensitivity (i.e. 
attenuation of a climate signal via lipid mixing) of the record. By selecting sites that maximize the signal to noise, more meaningful information can be obtained.

\subsection{Gaps and future directions}

- Understanding of the abundance, transport, preservation, fractionation and biological function of different wax compound classes is in its infancy. More studies are critically needed (with both modern and geologic based approaches) to assess and quantify how different $n$-alkyl compounds respond to and record biological and climatic change. This is a potential source of additional information about past environments and plant ecology that is waiting to be extracted.

- Relatively few studies have compared the relative abundance and stable isotopic composition of two or more $n$-alkyl lipid compound classes either in extant plants (Rommerskirchen et al., 2006; Chikaraishi and Naraoka, 2007; Vogts et al., 2009; Gao et al., 2015) or in sediments (Freeman and Colarusso, 2001; Feakins et al., 2007; Uno et al., 2016a). Therefore, sedimentary $n$-alkane and $n$ alkanoic acid records are frequently interpreted without respect to potential differences in production, isotopic fractionation, transport and preservation. This gap leaves several critical questions unresolved. For instance, do $n$-alkanes and $n$-alkanoic acids record different, complimentary, or similar records? Is there additional information that can be gained by measuring both? For example, do the two compound classes record disparate components of a catchment, possibly at different temporal scales? A concerted effort to compare compound classes needs to be undertaken in the coming years to address these questions.

- Residence times and sedimentary age offsets for terrestrial plant biomarkers in marine and lake sediments vary widely among sites. Advancing understanding of basin-specific controls on biomarker sources, transport pathways and residence times will be critical for developing accurate biomarker based reconstructions of climatic and environmental change.

I - Modern calibrations are the primary source of information about the mechanisms that explain the $\delta^{13} \mathrm{C}$ values produced in plant waxes. However, it is a challenge to reconcile the temporal and spatial scales of calibrations with those of the sediment record. The development of scaling relationships between the plant, forest, and sediment are needed. Future calibration studies could 
| greatly advance progress if they include multiple plant wax compounds and include wax concentration. But, greater effort should be placed on developing scaling relationships that connect extant plant wax to the sediment.

- Collaboration with plant physiologists and those studying plant evolution and paleobotany may be a promising way to help understand the origins and functions of plant waxes through geologic time. There may be further unexplored evolutionary or phylogenetic explanations for observed differences in plant wax abundance and composition among plant groups.

- Combining the $\delta^{13} \mathrm{C}$ and $\delta \mathrm{D}$ records of plant waxes in sediments may yield greater information about past climate, but to date, few studies have measured both stable isotopes.

- Future studies would greatly benefit from enhanced treatment of uncertainty. For example, $\mathrm{C}_{3} / \mathrm{C}_{4}$ vegetation studies often assume single end-member values, yet it is clear from the literature, especially for $\mathrm{C}_{3}$ plants, that there is a range of possible values. By adopting more rigorous methods for treating uncertainty (e.g. Polissar and D’Andrea, 2014; Tierney and Tingley, 2014), the community could assign uncertainties and probabilities to our predictions.

\section{Acknowledgements}

We thank R. Smittenberg, K. Uno and an anonymous reviewer for helpful comments that improved this review. Thanks go to D. Frost, K. McNultly and Y. Jee Suh for compiling data from the literature. We also thank A. Diefendorf for comments on earlier versions of the manuscript. Portions of the research were supported by the US National Science Foundation (EAR-1229114). Acknowledgement is made to the Donors of the American Chemical Society Petroleum Research Fund for partial support of the research (PRF \# 51787-DNI2).

Associate Editor - K.G.J. Nierop 


\section{Figure Captions}

I Fig. 1. Schematic of factors that influence the carbon isotopic composition of plant waxes following the flow of carbon from atmospheric $\mathrm{CO}_{2}$ into leaves and on to preservation in the geologic record. Factors that influence bulk leaf tissue and plant wax carbon isotopic fractionation are indicated with green arrows. Level of community understanding is based on $n$-alkanes and will be lower for other wax constituents (i.e. $n$-alkanols and $n$-alkanoic acids).

| Fig. 2. Plant wax concentration of (A) $n-\mathrm{C}_{29}$ alkane, (B) $n-\mathrm{C}_{31}$ alkane and (C) ACL $\left(\mathrm{C}_{27}-\mathrm{C}_{33}\right)$ for different growth forms separated by major taxonomic group and photosynthetic pathway. The $n$-alkane

| concentration is in $\mu \mathrm{g} / \mathrm{g}$ dry leaf and is plotted on a log scale. The number of samples in each group is indicated and $n$ is the same for both $n$-alkane chain lengths. There is a strong phylogenetic signal in the

| gymnosperm $n$-alkane concentration and ACL data that explains much of the observed variation (see Fig. 3). Box and whisker plots show the median, upper and lower quartiles, and maximum and minimum values, with outliers shown as dots. The data are a compilation from many studies (Collister et al., 1994b; Lockheart et al., 1997, 1998; Chikaraishi and Naraoka, 2003; Conte et al., 2003; Chikaraishi et al., 2004b; Nguyen Tu et al., 2004b; Bi et al., 2005; Krull et al., 2006; Rommerskirchen et al., 2006; Chikaraishi and Naraoka, 2007; Vogts et al., 2009; Bezabih et al., 2011; Diefendorf et al., 2011, 2015b; Duan and He, 2011; Mortazavi et al., 2012; Garcin et al., 2014; Badewien et al., 2015; Bush and McInerney, 2015)

| Fig. 3. n-Alkane concentration for conifer species and Ginkgo biloba collected at the same site in Berkeley, California. Conifer species are grouped into major clades with a DNA sequence-based phylogeny age-calibrated using the fossil record (Rai et al., 2008; Leslie et al., 2012). The $n$-alkane concentration ( $\mu \mathrm{g} / \mathrm{g}$ dry leaf) is reported for odd $n$-alkanes from $\mathrm{C}_{25}$ to $\mathrm{C}_{37}$ with ACL values indicated $\left(\mathrm{C}_{25}-\mathrm{C}_{37}\right)$. Box and whisker plots show the median, upper and lower quartiles, and maximum and minimum values, with outliers shown as dots. Figure is redrawn from Diefendorf et al. (2015b). 
Fig. 4. $\mathrm{ACL}\left(\mathrm{C}_{27}-\mathrm{C}_{35}\right)$ as a function of mean annual temperature $\left({ }^{\circ} \mathrm{C}\right.$ and $\left.\mathrm{K}\right)$ for $(\mathrm{A}) \mathrm{C}_{3}$ woody plants (including angiosperms and gymnosperms) and (B) $\mathrm{C}_{3}$ and $\mathrm{C}_{4}$ graminoids. A least squares regression line is plotted for reference with the $95 \%$ confidence of fit shaded for each line. MAT is not a predictor of ACL for woody plants or $\mathrm{C}_{3}$ graminoids. However, it is a predictor of ACL for $\mathrm{C}_{4}$ graminoids and explains $18 \%$ of the variability in ACL. Data are compiled from Bush and McInerney (2013) for the references therein that included geographic position, and from Diefendorf et al. (2011) and Diefendorf et

I al. (2015b). MAT is derived from the 1981-2010 long term mean GHCN Gridded V2 data provided by the NOAA/OAR/ESRL PSD, Boulder, Colorado, USA, from their web site at www.esrl.noaa.gov/psd/.

Fig. 5. The $\delta^{13} \mathrm{C}$ value of atmospheric $\mathrm{CO}_{2}$ estimated for the Cenozoic and based on the $\delta^{13} \mathrm{C}$ of benthic foraminifera. The blue line is a $3 \times 10^{6} \mathrm{yr}$ running average and the shaded box is the $90 \%$ confidence interval. Figure is redrawn from Tipple et al. (2010).

Fig. 6. A compilation of leaf discrimination $\left(\Delta_{\text {leaf }}\right)$ values surveyed from the literature as a function of mean annual precipitation (MAP). $\Delta_{\text {leaf }}$ was averaged for individuals of a species $(3,310$ total $)$ at each site, resulting in a total of 570 species-site combinations, 334 species and 75 families at 105 geographic sites. MAP accounts for $55 \%(p<0.0001)$ of the variability in $\Delta_{\text {leaf }}$ in a linear regression model (when MAP is $\log$ transformed to account for the log relationship of MAP to $\Delta_{\text {leaf }}$. Altitude is also an important predictor I of $\Delta_{\text {leaf }}$ and increases $\mathrm{R}^{2}$ to $0.61(p<0.0001)$ in a multiple linear regression model. The relationship between MAP and $\Delta_{\text {leaf }}$ is shown for angiosperms and gymnosperms and indicates higher average $\Delta_{\text {leaf }}$ in angiosperms. The right $\mathrm{y}$-axis indicates the corresponding approximate $\delta^{13} \mathrm{C}$ values. Points are coded by biome: tropical rain forest (TRF), evergreen warm mixed forest (EWMF), tropical seasonal forest (TSF), cool-cold deciduous forest (CCDF), cool-cold evergreen forest (CCEF), cool-cold mixed forest (CCMF), tropical deciduous forest (TDF), xeric woodland scrubland (XWS). Figure is redrawn from Diefendorf et al. (2010).

Fig. 7. Histogram of plant $\delta^{13} \mathrm{C}$ values with $\mathrm{C}_{3}$ and $\mathrm{C}_{4}$ distributions indicated. For reference, approximate $\Delta_{\text {leaf }}$ values are shown (assuming $\delta^{13} \mathrm{C}_{\mathrm{atm}}-8 \%$ ). The larger $\delta^{13} \mathrm{C}$ spread in $\mathrm{C}_{3}$ plants is related to the strong 
environmental and biological factors that influence fractionation. The figure is redrawn from Tipple and Pagani (2007) and reports data from Cerling and Harris (1999).

| Fig. 8. Carbon isotope fractionation during $n$-alkane biosynthesis for $n$ - $\mathrm{C}_{29}\left(\varepsilon_{n}\right.$-C29 alkane-leaf $)$ for different growth forms separated by major taxonomic group and photosynthetic pathway. The number of samples in each group is indicated. The data are a compilation from studies listed in Fig. 2. Additional information is found in Table 2 and Table E-1.

| Fig 9. Carbon isotope fractionation during $n$-alkane biosynthesis for conifers. Values are weighted by $n$ -

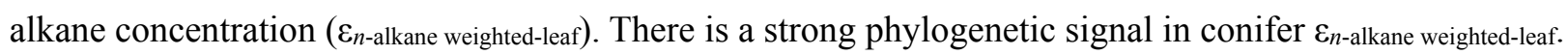
Box and whisker plots show the median, upper and lower quartiles, and maximum and minimum values. Each black dot represents a different species. Box color and order matches those of Figure 3. Figure is redrawn from Diefendorf et al. (2015b).

| Fig 10. $\delta^{13} \mathrm{C}$ values of $n-\mathrm{C}_{31}$ alkane and soil organic matter (SOM) for different African ecosystem types. Figure is reproduced from Magill et al. (2013). [FIGURE REQUIRES COPYRIGHT APPROVAL].

I Fig. 11. $\delta^{13} \mathrm{C}$ values of different plant functional types sampled along a latitudinal transect in Cameroon for $n-\mathrm{C}_{27}(\mathrm{~A}), n-\mathrm{C}_{29}$ (B), $n-\mathrm{C}_{31}$ (C), and $n-\mathrm{C}_{33}$ alkanes (D). Figure is reproduced from Garcin et al. (2014). [FIGURE REQUIRES COPYRIGHT APPROVAL]. 


\section{Tables}

Table 1

n-Alkane concentration and ACL for different plant functional types.

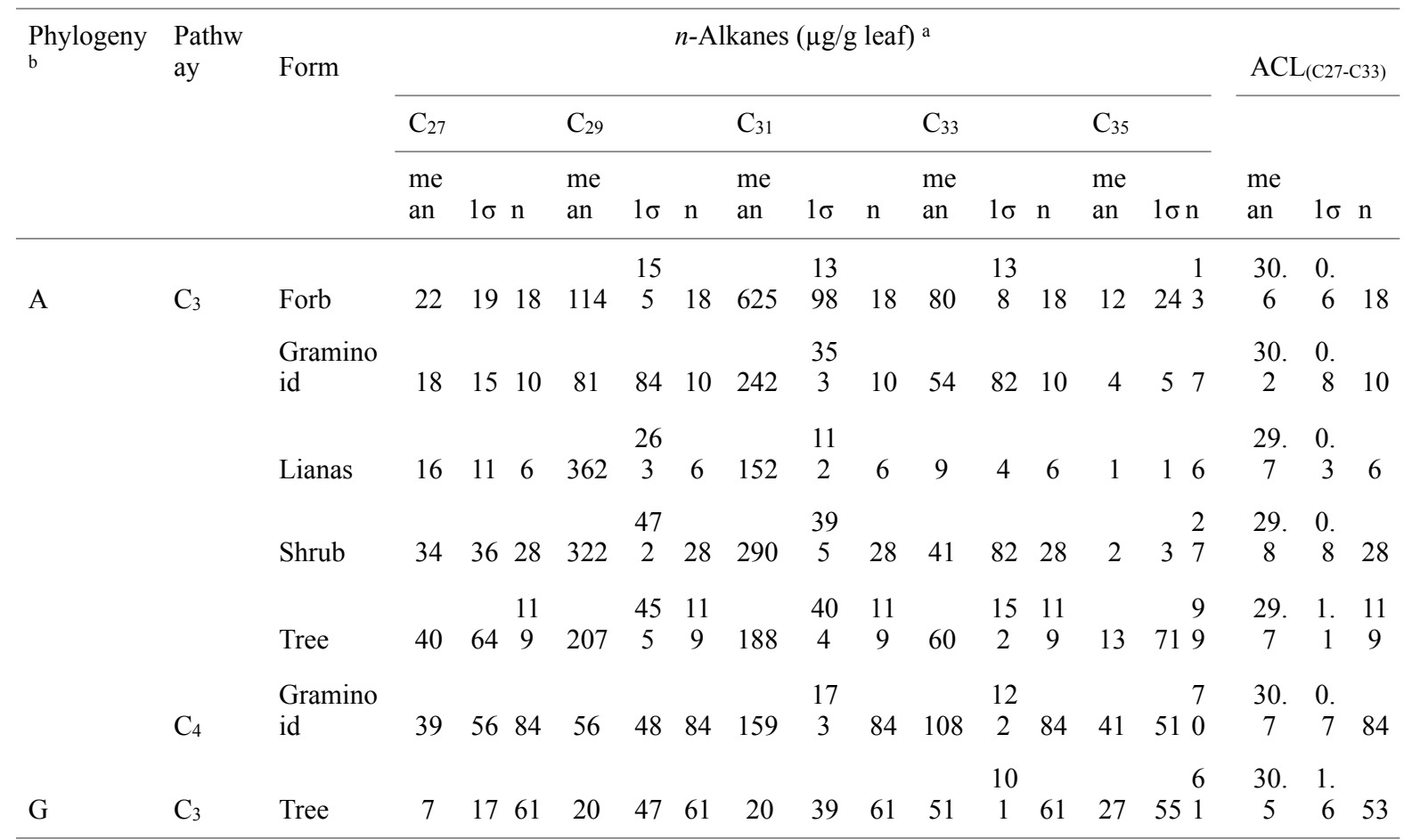

a Data sources are listed in Fig. 2 caption and reported in Table E-1

${ }^{\mathrm{b}}$ Angiosperms (A), Gymnosperms (G); the gymnosperms are all conifers, except for 2 Ginkgo biloba samples. 
Table 2

$n$-Alkane biosynthetic fractionation factor ( $\left.\varepsilon_{n \text {-alkanes-leaf }}\right)$ for different plant functional types.

\begin{tabular}{|c|c|c|c|c|c|c|c|c|c|c|c|c|c|c|c|c|c|c|}
\hline \multirow{3}{*}{$\begin{array}{l}\text { Phylogen } \\
y^{b}\end{array}$} & \multirow{3}{*}{$\begin{array}{l}\text { Pathw } \\
\text { ay }\end{array}$} & \multirow{3}{*}{ Form } & \multirow{3}{*}{$\begin{array}{l}\text { Lat. Zone } \\
\mathrm{c}\end{array}$} & \multicolumn{15}{|c|}{$\varepsilon_{n \text {-alkanes-leaf }} \% \mathrm{VPDB}^{\text {a }}$} \\
\hline & & & & \multicolumn{3}{|l|}{$\mathrm{C}_{27}$} & \multicolumn{3}{|l|}{$\mathrm{C}_{29}$} & \multicolumn{3}{|l|}{$\mathrm{C}_{31}$} & \multicolumn{3}{|l|}{$\mathrm{C}_{33}$} & \multicolumn{3}{|l|}{$\mathrm{C}_{35}$} \\
\hline & & & & $\begin{array}{l}\text { Mea } \\
\mathrm{n}\end{array}$ & $1 \sigma$ & $\mathrm{n}$ & $\begin{array}{l}\mathrm{Me} \\
\text { an }\end{array}$ & $1 \sigma$ & $\mathrm{n}$ & $\begin{array}{l}\mathrm{Me} \\
\text { an }\end{array}$ & $\begin{array}{l}1 \\
\sigma\end{array}$ & $\mathrm{n}$ & $\begin{array}{l}\text { Me } \\
\text { an }\end{array}$ & $\begin{array}{l}1 \\
\sigma\end{array}$ & $\mathrm{n}$ & $\begin{array}{l}\mathrm{Me} \\
\text { an }\end{array}$ & $\begin{array}{l}1 \\
\sigma\end{array}$ & $\mathrm{n}$ \\
\hline \multirow[t]{16}{*}{ A } & $\mathrm{C}_{3}$ & Forb & All & -6.9 & 2.6 & 11 & -7.3 & $\begin{array}{c}2 . \\
1\end{array}$ & 20 & -8.0 & $\begin{array}{c}2 . \\
0\end{array}$ & 20 & -8.2 & $\begin{array}{l}1 . \\
9\end{array}$ & 16 & 1.1 & & 1 \\
\hline & & & $\begin{array}{l}\text { Temperat } \\
\text { e }\end{array}$ & -8.7 & & 1 & -7.2 & $\begin{array}{l}0 . \\
7\end{array}$ & 2 & -6.5 & $\begin{array}{l}1 . \\
4\end{array}$ & 2 & -6.9 & $\begin{array}{l}0 . \\
2\end{array}$ & 2 & & & 0 \\
\hline & & & $\begin{array}{l}\text { Trop./ } \\
\text { Sub. }\end{array}$ & -6.7 & 2.7 & 10 & -7.3 & $\begin{array}{l}2 . \\
3\end{array}$ & 18 & -8.2 & $\begin{array}{c}2 . \\
0\end{array}$ & 18 & -8.4 & $\begin{array}{l}1 . \\
9\end{array}$ & 14 & 1.1 & & 1 \\
\hline & & $\begin{array}{l}\text { Gramin } \\
\text { oid }\end{array}$ & All & -4.8 & 2.5 & 6 & -6.0 & $\begin{array}{l}2 . \\
0\end{array}$ & 7 & -6.3 & $\begin{array}{l}1 . \\
1\end{array}$ & 7 & -6.3 & $\begin{array}{l}1 . \\
2\end{array}$ & 7 & & & 0 \\
\hline & & & $\begin{array}{l}\text { Temperat } \\
\text { e }\end{array}$ & -5.7 & 0.7 & 3 & -6.6 & $\begin{array}{l}0 . \\
9\end{array}$ & 4 & -5.8 & $\begin{array}{l}0 . \\
2\end{array}$ & 4 & -6.1 & $\begin{array}{l}1 . \\
1\end{array}$ & 4 & & & 0 \\
\hline & & & $\begin{array}{l}\text { Trop./ } \\
\text { Sub. }\end{array}$ & -4.0 & 3.6 & 3 & -5.1 & $\begin{array}{l}2 . \\
9\end{array}$ & 3 & -7.1 & $\begin{array}{l}1 . \\
3\end{array}$ & 3 & -6.6 & $\begin{array}{l}1 . \\
5\end{array}$ & 3 & & & 0 \\
\hline & & Shrub & $\begin{array}{l}\text { Trop./ } \\
\text { Sub. }^{d}\end{array}$ & -5.7 & 2.3 & 9 & -7.4 & $\begin{array}{l}2 . \\
2\end{array}$ & 22 & -7.4 & $\begin{array}{l}2 . \\
2\end{array}$ & 19 & -7.0 & $\begin{array}{l}1 . \\
9\end{array}$ & 10 & -9.0 & & 1 \\
\hline & & & & & & & & 2. & & & 2. & & & 2. & & & 2. & \\
\hline & & Tree & All & -4.3 & 2.1 & 93 & -5.2 & 4 & 109 & -5.6 & 5 & 104 & -5.4 & 7 & 71 & -3.4 & 7 & 15 \\
\hline & & & $\begin{array}{l}\text { Temperat } \\
\text { e }\end{array}$ & -4.1 & 1.6 & 32 & -4.6 & $\begin{array}{l}2 . \\
2\end{array}$ & 35 & -5.1 & $\begin{array}{l}2 . \\
2\end{array}$ & 31 & -5.8 & $\begin{array}{l}1 . \\
8\end{array}$ & 14 & -6.1 & $\begin{array}{l}4 . \\
0\end{array}$ & 2 \\
\hline & & & $\begin{array}{l}\text { Trop./ } \\
\text { Sub. }\end{array}$ & -4.4 & 2.4 & 61 & -5.5 & $\begin{array}{l}2 . \\
5\end{array}$ & 74 & -5.8 & $\begin{array}{l}2 . \\
7\end{array}$ & 73 & -5.3 & $\begin{array}{l}2 . \\
9\end{array}$ & 57 & -2.9 & $\begin{array}{l}2 . \\
3\end{array}$ & 13 \\
\hline & $\mathrm{C}_{4}$ & $\begin{array}{l}\text { Gramin } \\
\text { oid }\end{array}$ & All & -8.4 & 1.6 & 17 & -9.3 & $\begin{array}{c}2 . \\
1\end{array}$ & 24 & -9.0 & $\begin{array}{l}1 . \\
9\end{array}$ & 25 & -8.3 & $\begin{array}{l}1 . \\
5\end{array}$ & 20 & -8.9 & $\begin{array}{l}1 . \\
5\end{array}$ & 6 \\
\hline & & & $\begin{array}{l}\text { Temperat } \\
\text { e }\end{array}$ & & & & $\begin{array}{c}-10 . \\
5\end{array}$ & $\begin{array}{l}2 . \\
3\end{array}$ & 2 & -9.4 & $\begin{array}{l}2 . \\
6\end{array}$ & 2 & -7.7 & $\begin{array}{l}0 . \\
2\end{array}$ & 2 & -8.3 & $\begin{array}{l}0 . \\
8\end{array}$ & 2 \\
\hline & & & $\begin{array}{l}\text { Trop./ } \\
\text { Sub. }\end{array}$ & -8.4 & 1.6 & 17 & -9.2 & $\begin{array}{l}2 . \\
2\end{array}$ & 22 & -9.0 & $\begin{array}{l}1 . \\
9\end{array}$ & 23 & -8.3 & $\begin{array}{l}1 . \\
6\end{array}$ & 18 & -9.2 & $\begin{array}{l}1 . \\
8\end{array}$ & 4 \\
\hline & & Forb & $\begin{array}{l}\text { Trop./ } \\
\text { Sub. d }\end{array}$ & $\begin{array}{c}-11 . \\
1\end{array}$ & 0.2 & 2 & $\begin{array}{c}-11 . \\
1\end{array}$ & $\begin{array}{l}0 . \\
7\end{array}$ & 2 & $\begin{array}{c}-10 . \\
3\end{array}$ & $\begin{array}{l}1 . \\
2\end{array}$ & 3 & $\begin{array}{c}-11 . \\
0\end{array}$ & $\begin{array}{l}2 . \\
7\end{array}$ & 2 & & & 0 \\
\hline & & & & & & & & 2. & & & 2. & & & 2. & & & 2. & \\
\hline \multirow[t]{3}{*}{ G } & $\mathrm{C}_{3}$ & Tree & All & -4.2 & 2.7 & 32 & -4.2 & 7 & 41 & -4.5 & 5 & 44 & -3.7 & 4 & 43 & -3.0 & 8 & 29 \\
\hline & & & $\begin{array}{l}\text { Temperat } \\
\mathrm{e}\end{array}$ & -3.7 & 2.8 & 26 & -3.8 & $\begin{array}{l}3 . \\
0\end{array}$ & 31 & -4.3 & $\begin{array}{l}2 . \\
6\end{array}$ & 34 & -3.4 & $\begin{array}{l}2 . \\
4\end{array}$ & 33 & -2.5 & $\begin{array}{l}2 . \\
8\end{array}$ & 19 \\
\hline & & & $\begin{array}{l}\text { Trop./ } \\
\text { Sub. }\end{array}$ & -6.1 & 0.6 & 6 & -5.3 & $\begin{array}{l}1 . \\
4\end{array}$ & 10 & -5.1 & $\begin{array}{l}1 . \\
9\end{array}$ & 10 & -4.5 & $\begin{array}{l}2 . \\
3\end{array}$ & 10 & -3.9 & $\begin{array}{l}2 . \\
8\end{array}$ & 10 \\
\hline
\end{tabular}

${ }^{a}$ Data sources are listed in Fig. 1 caption and reported in Table E-1.

${ }^{\mathrm{b}}$ Angiosperms (A), gymnosperms (G); the gymnosperms are all conifers, except for 2 Ginkgo biloba samples.

c Temperate (Temp.), tropical/subtropical (Trop./Sub.)

${ }^{\mathrm{d}}$ All lianas, shrubs, and forbs are tropical and/or subtropical 


\section{References}

Aichner, B., Herzschuh, U., Wilkes, H., 2010. Influence of aquatic macrophytes on the stable carbon isotopic signatures of sedimentary organic matter in lakes on the Tibetan Plateau. Organic Geochemistry 41, 706-718.

Arneth, A., Lloyd, J., Šantrůčková, H., Bird, M., Grigoryev, S., Kalaschnikov, Y.N., Gleixner, G., Schulze, E.D., 2002. Response of central Siberian Scots pine to soil water deficit and long-term trends in atmospheric $\mathrm{CO}_{2}$ concentration. Global Biogeochemical Cycles 16, 5-1-5-13.

Axelrod, D.I., 1987. The late Oligocene Creede flora, Colorado. University of California Publications in Geological Sciences 130, 180-198.

| Baas, M., Pancost, R., van Geel, B., Sinninghe Damsté, J.S., 2000. A comparative study of lipids in Sphagnum species. Organic Geochemistry 31, 535-541.

Baczynski, A.A., McInerney, F.A., Wing, S.L., Kraus, M.J., Bloch, J.I., Boyer, D.M., Secord, R., Morse, P.E., Fricke, H.C., 2013. Chemostratigraphic implications of spatial variation in the PaleoceneEocene Thermal Maximum carbon isotope excursion, SE Bighorn Basin, Wyoming. Geochemistry, Geophysics, Geosystems 14, 4133-4152.

Baczynski, A.A., McInerney, F.A., Wing, S.L., Kraus, M.J., Morse, P.E., Bloch, J.I., Chung, A.H., Freeman, K.H., 2016. Distortion of carbon isotope excursion in bulk soil organic matter during the Paleocene-Eocene thermal maximum. Geological Society of America Bulletin.

Badewien, T., Vogts, A., Rullkötter, J., 2015. n-Alkane distribution and carbon stable isotope composition in leaf waxes of $C_{3}$ and $C_{4}$ plants from Angola. Organic Geochemistry 89-90, 71-79.

Baker, E.A., Hunt, G.M., 1986. Erosion of waxes from leaf surfaces by simulated rain. New Phytologist $102,161-173$.

Bargel, H., Koch, K., Cerman, Z., Neinhuis, C., 2006. Structure-function relationships of the plant cuticle and cuticular waxes - a smart material? Functional Plant Biology 33, 893-910.

Bataille, C.P., Mastalerz, M., Tipple, B.J., Bowen, G.J., 2013. Influence of provenance and preservation on the carbon isotope variations of dispersed organic matter in ancient floodplain sediments. Geochemistry, Geophysics, Geosystems 14, 4874-4891. 
Bechtel, A., Sachsenhofer, R.F., Gratzer, R., Lücke, A., Püttmann, W., 2002. Parameters determining the carbon isotopic composition of coal and fossil wood in the Early Miocene Oberdorf lignite seam (Styrian Basin, Austria). Organic Geochemistry 33, 1001-1024.

Bechtel, A., Gratzer, R., Sachsenhofer, R.F., Gusterhuber, J., Lücke, A., Püttmann, W., 2008. Biomarker and carbon isotope variation in coal and fossil wood of Central Europe through the Cenozoic. Palaeogeography, Palaeoclimatology, Palaeoecology 262, 166-175.

Beerling, D.J., 1996. Ecophysiological responses of woody plants to past $\mathrm{CO}_{2}$ conentrations. Tree Physiology 16, 389-396.

Beerling, D.J., Royer, D.L., 2002. Fossil plants as indicators of the Phanerozoic global carbon cycle. Annual Reviews of Earth and Planetary Sciences 30, 527-556.

Berner, R.A., Kothavala, Z., 2001. Geocarb III: A revised model of atmospheric $\mathrm{CO}_{2}$ over Phanerozoic time. American Journal of Science 301, 182-204.

Bert, D., Leavitt, S.W., Dupouey, J.-L., 1997. Variations of wood $\delta^{13} \mathrm{C}$ and water-use efficiency of Abies alba during the last century. Ecology 78, 1588-1596.

Bezabih, M., Pellikaan, W.F., Tolera, A., Hendriks, W.H., 2011. Evaluation of $n$-alkanes and their carbon isotope enrichments $\left(\delta^{13} \mathrm{C}\right)$ as diet composition markers. Animal 5, 57-66.

Bi, X., Sheng, G., Liu, X., Li, C., Fu, J., 2005. Molecular and carbon and hydrogen isotopic composition of $n$-alkanes in plant leaf waxes. Organic Geochemistry 36, 1405-1417.

Bingham, E.M., McClymont, E.L., Väliranta, M., Mauquoy, D., Roberts, Z., Chambers, F.M., Pancost, R.D., Evershed, R.P., 2010. Conservative composition of $n$-alkane biomarkers in Sphagnum species: implications for palaeoclimate reconstruction in ombrotrophic peat bogs. Organic Geochemistry 41, 214-220.

Bird, M.I., Summons, R.E., Gagan, M.K., Roksandic, Z., Dowling, L., Head, J., Keith Fifield, L., Cresswell, R.G., Johnson, D.P., 1995. Terrestrial vegetation change inferred from $n$-alkane $\delta^{13} \mathrm{C}$ analysis in the marine environment. Geochimica et Cosmochimica Acta 59, 2853-2857.

Bjorøy, M., Hall, P.B., Hustad, E., Williams, J.A., 1992. Variation in stable carbon isotope ratios of individual hydrocarbons as a function of artificial maturity. Organic Geochemistry 19, 89-105. 
Black, C.C., Jr, 1973. Photosynthetic carbon fixation in relation to net $\mathrm{CO}_{2}$ uptake. Annual Review of Plant Physiology 24, 253-286.

Blair, N.E., Leithold, E.L., Ford, S.T., Peeler, K.A., Holmes, J.C., Perkey, D.W., 2003. The persistence of memory: the fate of ancient sedimentary organic carbon in a modern sedimentary system. Geochimica et Cosmochimica Acta 67, 63-73.

Blair, N.E., Aller, R.C., 2012. The fate of terrestrial organic carbon in the marine environment. Ann Rev Mar Sci 4, 401-23.

Bonal, D., Sabatier, D., Montpied, P., Tremeaux, D., Guehl, J.M., 2000. Interspecific variability of $\delta^{13}$ C among trees in rainforests of French Guiana: functional groups and canopy integration. Oecologia $124,454-468$.

Bowen, G.J., Beerling, D.J., Koch, P.L., Zachos, J.C., Quattlebaum, T., 2004. A humid climate state during the Palaeocene/Eocene thermal maximum. Nature 432, 495-499.

Bowen, G.J., 2013. Up in smoke: A role for organic carbon feedbacks in Paleogene hyperthermals. Global and Planetary Change 109, 18-29.

Bowling, D., McDowell, N., Bond, B., Law, B., Ehleringer, J., 2002. ${ }^{13} \mathrm{C}$ content of ecosystem respiration is linked to precipitation and vapor pressure deficit. Oecologia 131, 113-124.

Brasell, H., Unwin, G., Stocker, G., 1980. The quantity, temporal distribution and mineral-element content of litterfall in two forest types at two sites in tropical Australia. The Journal of Ecology, 123-139.

Bray, E.E., Evans, E.D., 1961. Distribution of n-paraffins as a clue to recognition of source beds. Geochimica et Cosmochimica Acta 22, 2-15.

Bray, P.S., Brocks, J.J., George, S.C., 2014. ${ }^{14} \mathrm{C}$ analysis of aliphatic hydrocarbon fractions from the hypersaline Lake Tyrrell, southeast Australia. Organic Geochemistry 73, 29-34.

Brooks, J.D., Smith, J.W., 1967. The diagenesis of plant lipids during the formation of coal, petroleum and natural gas- - I. Changes in the $n$-paraffin hydrocarbons. Geochimica et Cosmochimica Acta $31,2389-2397$.

Brooks, J.R., Flanagan, L.B., Buchmann, N., Ehleringer, J.R., 1997. Carbon isotope composition of boreal plants: functional grouping of life forms. Oecologia 110, 301-311. 
Burnham, R.J., 1989. Relationships between standing vegetation and leaf litter in a paratropical forest: implications for paleobotany. Review of Palaeobotany and Palynology 58, 5-32.

Burnham, R.J., Wing, S.L., Parker, G.G., 1992. The reflection of deciduous forest communities in leaf litter; implications for autochthonous litter assemblages from the fossil record. Paleobiology 18, $30-49$

Burnham, R.J., 1994. Paleoecological and floristic heterogeneity in the plant-fossil record - an analysis based on the Eocene of Washington. United States Geological Survey Bulletin 2085-B, 1-36.

Bush, R.T., McInerney, F.A., 2013. Leaf wax $n$-alkane distributions in and across modern plants: Implications for paleoecology and chemotaxonomy. Geochimica et Cosmochimica Acta 117, 161-179.

Bush, R.T., McInerney, F.A., 2015. Influence of temperature and $\mathrm{C}_{4}$ abundance on $n$-alkane chain length distributions across the central USA. Organic Geochemistry 79, 65-73.

Carr, A.S., Boom, A., Grimes, H.L., Chase, B.M., Meadows, M.E., Harris, A., 2014. Leaf wax n-alkane distributions in arid zone South African flora: Environmental controls, chemotaxonomy and palaeoecological implications. Organic Geochemistry 67, 72-84.

Cerling, T.E., Harris, J.M., 1999. Carbon isotope fractionation between diet and bioapatite in ungulate mammals and implications for ecological and paleoecological studies. Oecologia 120, 347-363.

Cerling, T.E., Wynn, J.G., Andanje, S.A., Bird, M.I., Korir, D.K., Levin, N.E., Mace, W., Macharia, A.N., Quade, J., Remien, C.H., 2011. Woody cover and hominin environments in the past 6 million years. Nature 476, 51-56.

Cernusak, L.A., Ubierna, N., Winter, K., Holtum, J.A.M., Marshall, J.D., Farquhar, G.D., 2013. Environmental and physiological determinants of carbon isotope discrimination in terrestrial plants. New Phytologist 200, 950-965.

Chevalier, N., Savoye, N., Dubois, S., Lama, M.L., David, V., Lecroart, P., Ménach, K.l., Budzinski, H., 2015. Precise indices based on $n$-alkane distribution for quantifying sources sedimentary organic matter in coastal systems. Organic Geochemistry 88, 69-77.

Chikaraishi, Y., Naraoka, H., 2003. Compound-specific $\delta \mathrm{D}-\delta^{13} \mathrm{C}$ analyses of $n$-alkanes extracted from terrestrial and aquatic plants. Phytochemistry 63, 361-371. 
Chikaraishi, Y., Naraoka, H., Poulson, S.R., 2004a. Hydrogen and carbon isotopic fractionations of lipid biosynthesis among terrestrial $\left(\mathrm{C}_{3}, \mathrm{C}_{4}\right.$ and $\left.\mathrm{CAM}\right)$ and aquatic plants. Phytochemistry 65 , 1369-1381.

Chikaraishi, Y., Naraoka, H., Poulson, S.R., 2004b. Carbon and hydrogen isotopic fractionation during lipid biosynthesis in a higher plant (Cryptomeria japonica). Phytochemistry 65, 323-330.

Chikaraishi, Y., Naraoka, H., 2006. Carbon and hydrogen isotope variation of plant biomarkers in a plantsoil system. Chemical Geology 231, 190-202.

Chikaraishi, Y., Naraoka, H., 2007. $\delta^{13} \mathrm{C}$ and $\delta \mathrm{D}$ relationships among three n-alkyl compound classes $(n-$ alkanoic acid, $n$-alkane and $n$-alkanol) of terrestrial higher plants. Organic Geochemistry 38, $198-215$.

Clayton, C.J., Bjorøy, M., 1994. Effect of maturity on ${ }^{13} \mathrm{C} /{ }^{12} \mathrm{C}$ ratios of individual compounds in North Sea oils. Organic Geochemistry 21, 737-750.

Collins, J.A., Schefuß, E., Heslop, D., Mulitza, S., Prange, M., Zabel, M., Tjallingii, R., Dokken, T.M., Huang, E., Mackensen, A., 2011. Interhemispheric symmetry of the tropical African rainbelt over the past 23,000 years. Nature Geoscience 4, 42-45.

Collins, J.A., Schefuß, E., Mulitza, S., Prange, M., Werner, M., Tharammal, T., Paul, A., Wefer, G., 2013. Estimating the hydrogen isotopic composition of past precipitation using leaf-waxes from western Africa. Quaternary Science Reviews 65, 88-101.

Collister, J.W., Lichtfouse, E., Hieshima, G., Hayes, J.M., 1994a. Partial resolution of sources of nalkanes in the saline portion of the Parachute Creek Member, Green River Formation (Piceance Creek Basin, Colorado). Organic Geochemistry 21, 645-659.

Collister, J.W., Rieley, G., Stern, B., Eglinton, G., Fry, B., 1994b. Compound-specific $\delta^{13} \mathrm{C}$ analyses of leaf lipids from plants with differing carbon dioxide metabolisms. Organic Geochemistry 21, 619-627.

Conte, M., Weber, J., Carlson, P., Flanagan, L., 2003. Molecular and carbon isotopic composition of leaf wax in vegetation and aerosols in a northern prairie ecosystem. Oecologia 135, 67-77.

Conte, M.H., Weber, J.C., 2002. Long-range atmospheric transport of terrestrial biomarkers to the western North Atlantic. Global Biogeochemical Cycles 16, 89-1-89-17. 
Coplen, T.B., 2011. Guidelines and recommended terms for expression of stable-isotope-ratio and gasratio measurement results. Rapid Communications in Mass Spectrometry 25, 2538-2560.

Cranwell, P.A., 1981. Diagenesis of free and bound lipids in terrestrial detritus deposited in a lacustrine sediment. Organic Geochemistry 3, 79-89.

Cranwell, P.A., Eglinton, G., Robinson, N., 1987. Lipids of aquatic organisms as potential contributors to lacustrine sediments-II. Organic Geochemistry 11, 513-527.

de Leeuw, J.W., Frewin, N.L., Van Bergen, P.F., Sinninghe Damsté, J.S., Collinson, M.E., 1995. Organic carbon as a palaeoenvironmental indicator in the marine realm. In: Bosence, D.W., Allison, P.A.

| (Eds.), Marine Paleoenvironmental Analysis From Fossils 83, Geological Society Special Publication, pp. 43-71.

Deines, P., 1980. The isotopic composition of reduced organic carbon. In: Fritz, P., Fontes, J.C. (Eds.), | Handbook of Environmental Isotope Geochemistry. Elsevier, pp. 329-406.

Diefendorf, A.F., Mueller, K.E., Wing, S.L., Koch, P.L., Freeman, K.H., 2010. Global patterns in leaf ${ }^{13} \mathrm{C}$ discrimination and implications for studies of past and future climate. Proceedings of the National Academy of Sciences of the USA 107, 5738-5743.

Diefendorf, A.F., Freeman, K.H., Wing, S.L., Graham, H.V., 2011. Production of $n$-alkyl lipids in living plants and implications for the geologic past. Geochimica et Cosmochimica Acta 75, 7472-7485.

Diefendorf, A.F., Freeman, K.H., Wing, S.L., Currano, E.D., Mueller, K.E., 2015a. Paleogene plants fractionated carbon isotopes similar to modern plants. Earth and Planetary Science Letters 429, $33-44$.

Diefendorf, A.F., Leslie, A.B., Wing, S.L., 2015b. Leaf wax composition and carbon isotopes vary among major conifer groups. Geochimica et Cosmochimica Acta 170, 145-156.

Diefendorf, A.F., Sberna, D.T., Taylor, D.W., 2015c. Effect of thermal maturation on plant-derived terpenoids and leaf wax $n$-alkyl components. Organic Geochemistry 89-90, 61-70.

Douglas, P.M.J., Pagani, M., Brenner, M., Hodell, D.A., Curtis, J.H., 2012. Aridity and vegetation composition are important determinants of leaf-wax $\delta \mathrm{D}$ values in southeastern Mexico and Central America. Geochimica et Cosmochimica Acta 97, 24-45. 
Douglas, P.M.J., Pagani, M., Eglinton, T.I., Brenner, M., Hodell, D.A., Curtis, J.H., Ma, K.F., Breckenridge, A., 2014. Pre-aged plant waxes in tropical lake sediments and their influence on the chronology of molecular paleoclimate proxy records. Geochimica et Cosmochimica Acta 141, 346-364.

Drake, H., Burrows, C.J., 1980. The influx of potential macrofossils into Lady Lake, north Westland, New Zealand. New Zealand Journal of Botany 18, 257-274.

Drenzek, N.J., Montluçon, D.B., Yunker, M.B., Macdonald, R.W., Eglinton, T.I., 2007. Constraints on the origin of sedimentary organic carbon in the Beaufort Sea from coupled molecular ${ }^{13} \mathrm{C}$ and ${ }^{14} \mathrm{C}$ measurements. Marine Chemistry 103, 146-162.

Drenzek, N.J., Hughen, K.A., Montlucon, D.B., Southon, J.R., dos Santos, G.M., Druffel, E.R.M., Giosan, L., Eglinton, T.I., 2009. A new look at old carbon in active margin sediments. Geology $37,239-242$.

Duan, Y.I., He, J., 2011. Distribution and isotopic composition of $n$-alkanes from grass, reed and tree leaves along a latitudinal gradient in China. Geochemical Journal 45, 199-207.

Duce, R.A., Gagosian, R.B., 1982. The input of atmospheric $n-\mathrm{C}_{10}$ to $n$ - $\mathrm{C}_{30}$ alkanes to the ocean. Journal of Geophysical Research: Oceans 87, 7192-7200.

Dungait, J.A.J., Docherty, G., Straker, V., Evershed, R.P., 2008. Interspecific variation in bulk tissue, fatty acid and monosaccharide $\delta^{13} \mathrm{C}$ values of leaves from a mesotrophic grassland plant community. Phytochemistry 69, 2041-2051.

Duquesnay, A., Bréda, N., Stievenard, M., Dupouey, J.L., 1998. Changes of tree-ring $\delta^{13} \mathrm{C}$ and water-use efficiency of beech (Fagus sylvatica L.) in north-eastern France during the past century. Plant, Cell \& Environment 21, 565-572.

Edwards, E.J., Osborne, C.P., Strömberg, C.A.E., Smith, S.A., Consortium, C.G., 2010. The origins of C 4 grasslands: Integrating evolutionary and ecosystem science. Science 328, 587-591.

Edwards, E.J., Smith, S.A., 2010. Phylogenetic analyses reveal the shady history of $\mathrm{C}_{4}$ grasses. Proceedings of the National Academy of Sciences of the USA 107, 2532-2537.

Eglinton, G., Gonzalez, A.G., Hamilton, R.J., Raphael, R.A., 1962. Hydrocarbon constituents of the wax coatings of plant leaves: A taxonomic survey. Phytochemistry 1, 89-102. 
Eglinton, G., Hamilton, R.J., 1963. The distribution of n-alkanes. In: Swain, T. (Ed.), Chemical Plant | Taxonomy. Academic Press, pp. 197-217.

Eglinton, G., Hamilton, R.J., 1967. Leaf epicuticular waxes. Science 156, 1322-1335.

Eglinton, T.I., 1994. Carbon isotopic evidence for the origin of macromolecular aliphatic structures in kerogen. Organic Geochemistry 21, 721-735.

Eglinton, T.I., Aluwihare, L.I., Bauer, J.E., Druffel, E.R.M., McNichol, A.P., 1996. Gas chromatographic isolation of individual compounds from complex matrices for radiocarbon dating. Analytical Chemistry 68, 904-912.

Eglinton, T.I., Benitez-Nelson, B.C., Pearson, A., McNichol, A.P., Bauer, J.E., Druffel, E.R.M., 1997. Variability in radiocarbon ages of individual organic compounds from marine sediments. Science 277, 796-799.

Ehleringer, J., Phillips, S., Schuster, W.F., Sandquist, D., 1991. Differential utilization of summer rains by desert plants. Oecologia 88, 430-434.

Ehleringer, J.R., Phillips, S.L., Comstock, J.P., 1992. Seasonal variation in the carbon isotopic composition of desert plants. Functional Ecology 6, 396-404.

Ehleringer, J.R., Cerling, T.E., 1995. Atmospheric $\mathrm{CO}_{2}$ and the ratio of intercellular to ambient $\mathrm{CO}_{2}$ concentrations in plants. Tree Physiology 15, 105-111.

Eichmann, R., Neuling, P., Ketseridis, G., Hahn, J., Jaenicke, R., Junge, C., 1979. n-Alkane studies in the troposphere-I. Gas and particulate concentrations in north Atlantic air. Atmospheric Environment 13, 587-599.

Eichmann, R., Ketseridis, G., Schebeske, G., Jaenicke, R., Hahn, J., Warneck, P., Junge, C., 1980. nAlkane studies in the troposphere-II: Gas and particulate concentrations in Indian Ocean air. Atmospheric Environment 14, 695-703.

Ellis, B., Johnson, K.R., 2013. Comparison of leaf samples from mapped tropical and temperate forests: implications for interpretations of the diversity of fossil assemblages. PALAIOS 28, 163-177.

Farquhar, G.D., O'Leary, M.H., Berry, J.A., 1982. On the relationship between carbon isotope discrimination and the intercellular carbon dioxide concentration in leaves. Australian Journal of Plant Physiology 9, 121-137. 
Farquhar, G.D., 1983. On the nature of carbon isotope discrimination in $\mathrm{C}_{4}$ species. Australian Journal of Plant Physiology 10, 205-226.

Farquhar, G.D., Richards, R.A., 1984. Isotopic composition of plant carbon correlates with water-use efficiency of wheat genotypes. Australian Journal of Plant Physiology 11, 539-552.

Farquhar, G.D., Ehleringer, J.R., Hubick, K.T., 1989. Carbon isotope discrimination and photosynthesis. Annual Review of Plant Physiology and Plant Molecular Biology 40, 503-537.

Feakins, S.J., Eglinton, T.I., deMenocal, P.B., 2007. A comparison of biomarker records of northeast African vegetation from lacustrine and marine sediments (ca. 3.40 Ma). Organic Geochemistry $38,1607-1624$.

Feakins, S.J., Levin, N.E., Liddy, H.M., Sieracki, A., Eglinton, T.I., Bonnefille, R., 2013. Northeast African vegetation change over 12 m.y. Geology.

Feng, X., Vonk, J.E., van Dongen, B.E., Gustafsson, Ö., Semiletov, I.P., Dudarev, O.V., Wang, Z., Montluçon, D.B., Wacker, L., Eglinton, T.I., 2013. Differential mobilization of terrestrial carbon pools in Eurasian Arctic river basins. Proceedings of the National Academy of Sciences 110, 14168-14173.

Ficken, K.J., Li, B., Swain, D.L., Eglinton, G., 2000. An $n$-alkane proxy for the sedimentary input of submerged/floating freshwater aquatic macrophytes. Organic Geochemistry 31, 745-749.

Finch, P., Freeman, G., 2001. Simulated diagenesis of plant cuticles — implications for organic fossilisation. Journal of Analytical and Applied Pyrolysis 58-59, 229-235.

France-Lanord, C., Derry, L.A., 1994. $\delta^{13} \mathrm{C}$ of organic carbon in the Bengal Fan: Source evolution and transport of $\mathrm{C}_{3}$ and $\mathrm{C}_{4}$ plant carbon to marine sediments. Geochimica et Cosmochimica Acta 58, 4809-4814.

Franks, P.J., Beerling, D.J., 2009. $\mathrm{CO}_{2}$ forced evolution of plant gas exchange capacity and water-use efficiency over the Phanerozoic. Geobiology 7, 227-236.

Franks, P.J., Royer, D.L., Beerling, D.J., Van de Water, P.K., Cantrill, D.J., Barbour, M.M., Berry, J.A., 2014. New constraints on atmospheric $\mathrm{CO}_{2}$ concentration for the Phanerozoic. Geophysical Research Letters 41, 2014 GL060457. 
Freeman, K.H., Colarusso, L.A., 2001. Molecular and isotopic records of $\mathrm{C}_{0}$ grassland expansion in the late Miocene. Geochimica et Cosmochimica Acta 65, 1439-1454.

Freeman, K.H., Mueller, K.E., Diefendorf, A.F., Wing, S.L., Koch, P.L., 2011. Clarifying the influence of water availability and plant types on carbon isotope discrimination by $\mathrm{C}_{3}$ plants. Proceedings of | the National Academy of Sciences of the USA 108, E59-E60.

Freeman, K.H., Pancost, R.D., 2014. Biomarkers for terrestrial plants and climate. In: Turekian, H.D., Holland, K.K. (Eds.), Treatise on Geochemistry (Second Edition). Elsevier, pp. 395-416.

Galy, V., Eglinton, T., 2011. Protracted storage of biospheric carbon in the Ganges-Brahmaputra basin. Nature Geoscience 4, 843-847.

Galy, V., Peucker-Ehrenbrink, B., Eglinton, T., 2015. Global carbon export from the terrestrial biosphere controlled by erosion. Nature 521, 204-207.

Gamarra, B., Kahmen, A., 2015. Concentrations and $\delta^{2} \mathrm{H}$ values of cuticular $n$-alkanes vary significantly among plant organs, species and habitats in grasses from an alpine and a temperate European grassland. Oecologia 178, 981-998.

Gao, L., Guimond, J., Thomas, E., Huang, Y., 2015. Major trends in leaf wax abundance, $\delta^{2} \mathrm{H}$ and $\delta^{13} \mathrm{C}$ values along leaf venation in five species of $\mathrm{C}_{3}$ plants: Physiological and geochemical implications. Organic Geochemistry 78, 144-152.

Garcin, Y., Schefuß, E., Schwab, V.F., Garreta, V., Gleixner, G., Vincens, A., Todou, G., Séné, O., Onana, J.-M., Achoundong, G., Sachse, D., 2014. Reconstructing $\mathrm{C}_{3}$ and $\mathrm{C}_{4}$ vegetation cover using $n$ alkane carbon isotope ratios in recent lake sediments from Cameroon, Western Central Africa. Geochimica et Cosmochimica Acta 142, 482-500.

Gierga, M., Hajdas, I., van Raden, U.J., Gilli, A., Wacker, L., Sturm, M., Bernasconi, S.M., Smittenberg, R.H., 2016. Long-stored soil carbon released by prehistoric land use: Evidence from compoundspecific radiocarbon analysis on Soppensee lake sediments. Quaternary Science Reviews 144, $123-131$.

Goñi, M.A., Yunker, M.B., Macdonald, R.W., Eglinton, T.I., 2005. The supply and preservation of ancient and modern components of organic carbon in the Canadian Beaufort Shelf of the Arctic Ocean. Marine Chemistry 93, 53-73. 
Graham, H.V., Patzkowsky, M.E., Wing, S.L., Parker, G.G., Fogel, M.L., Freeman, K.H., 2014. Isotopic characteristics of canopies in simulated leaf assemblages. Geochimica et Cosmochimica Acta $144,82-95$.

Greenwood, D.R., 1991. The taphonomy of plant macrofossils. In: Donovan, S.K. (Ed.), The processes of | fossilization. Belhaven Press, pp. 141-169.

Gupta, N.S., Collinson, M.E., Briggs, D.E.G., Evershed, R.P., Pancost, R.D., 2006. Reinvestigation of the occurrence of cutan in plants: implications for the leaf fossil record. Paleobiology 32, 432-449.

Gupta, N.S., Briggs, D.E.G., Collinson, M.E., Evershed, R.P., Michels, R., Jack, K.S., Pancost, R.D., 2007a. Evidence for the in situ polymerisation of labile aliphatic organic compounds during the preservation of fossil leaves: Implications for organic matter preservation. Organic Geochemistry $38,499-522$.

Gupta, N.S., Michels, R., Briggs, D.E.G., Collinson, M.E., Evershed, R.P., Pancost, R.D., $2007 b$. Experimental evidence for the formation of geomacromolecules from plant leaf lipids. Organic Geochemistry 38, 28-36.

Gupta, N.S., 2014. Distribution of Cutan in Modern Leaves. In: Biopolymers, 38, Topics in Geobiology, Springer Netherlands, pp. 17-41.

Häggi, C., Zech, R., McIntyre, C., Zech, M., Eglinton, T.I., 2014. On the stratigraphic integrity of leafwax biomarkers in loess paleosols. Biogeosciences 11, 2455-2463.

Handley, L., Pearson, P.N., McMillan, I.K., Pancost, R.D., 2008. Large terrestrial and marine carbon and hydrogen isotope excursions in a new Paleocene/Eocene boundary section from Tanzania. Earth and Planetary Science Letters 275, 17-25.

Hartnett, H.E., Keil, R.G., Hedges, J.I., Devol, A.H., 1998. Influence of oxygen exposure time on organic carbon preservation in continental margin sediments. Nature 391, 572-575.

Hatch, M.D., 1987. C4 photosynthesis: a unique blend of modified biochemistry, anatomy and ultrastructure. Biochimica et Biophysica Acta (BBA) - Reviews on Bioenergetics 895, 81-106.

Hattersley, P., 1982. $\delta^{13}$ values of $\mathrm{C}_{4}$ types in grasses. Australian Journal of Plant Physiology 9, 139-154. Hayes, J.M., 1993. Factors controlling 13C contents of sedimentary organic compounds: Principles and evidence. Marine Geology 113, 111-125. 
Hayes, J.M., Strauss, H., Kaufman, A.J., 1999. The abundance of ${ }^{13} \mathrm{C}$ in marine organic matter and isotopic fractionation in the global biogeochemical cycle of carbon during the past $800 \mathrm{Ma}$. Chemical Geology 161, 103-125.

Hayes, J.M., 2001. Fractionation of carbon and hydrogen isotopes in biosynthetic processes. Reviews in Mineralogy and Geochemistry 43, 225-277.

Hedges, J.I., Prahl, F.G., 1993. Early diagenesis: consequences for applications of molecular biomarkers. In: Engel, M.H., Macko, S.A. (Eds.), Organic Geochemistry - Principles and Applications. Plenum Press, pp. 237-253.

Hedges, J.I., Oades, J.M., 1997. Comparative organic geochemistries of soils and marine sediments. Organic Geochemistry 27, 319-361.

Hemingway, J.D., Schefuß, E., Dinga, B.J., Pryer, H., Galy, V.V., 2016. Multiple plant-wax compounds record differential sources and ecosystem structure in large river catchments. Geochimica et Cosmochimica Acta 184, 20-40.

Hoefs, M.J.L., Rijpstra, W.I.C., Sinninghe Damsté, J.S., 2002. The influence of oxic degradation on the sedimentary biomarker record I: evidence from Madeira Abyssal Plain turbidites. Geochimica et Cosmochimica Acta 66, 2719-2735.

Hoetzel, S., Dupont, L., Schefuß, E., Rommerskirchen, F., Wefer, G., 2013. The role of fire in Miocene to | Pliocene $\mathrm{C}_{4}$ grassland and ecosystem evolution. Nature Geoscience 6, 1027-1030.

Hoffmann, B., Kahmen, A., Cernusak, L.A., Arndt, S.K., Sachse, D., 2013. Abundance and distribution of leaf wax $n$-alkanes in leaves of Acacia and Eucalyptus trees along a strong humidity gradient in northern Australia. Organic Geochemistry 62, 62-67.

Huang, Y., Lockheart, M.J., Collister, J.W., Eglinton, G., 1995. Molecular and isotopic biogeochemistry of the Miocene Clarkia Formation: hydrocarbons and alcohols. Organic Geochemistry 23, 785-801.

Huang, Y., Eglinton, G., Ineson, P., Latter, P.M., Bol, R., Douglas, D.D., 1997. Absence of carbon isotope fractionation of individual $n$-alkanes in a 23 year field decomposition experiment with Calluna vulgaris. Organic Geochemistry 26, 497-501. 
Huang, Y., Dupont, L., Sarnthein, M., Hayes, J.M., Eglinton, G., 2000. Mapping of $\mathrm{C}_{4}$ plant input from North West Africa into North East Atlantic sediments. Geochimica et Cosmochimica Acta 64, $3505-3513$.

Jetter, R., Schaffer, S., Riederer, M., 2000. Leaf cuticular waxes are arranged in chemically and mechanically distinct layers: evidence from Prunus laurocerasus L. Plant Cell and Environment 23, 619-628.

Kaplan, J.O., Prentice, C., Buchmann, N., 2002. The stable carbon isotope composition of the terrestrial biosphere: Modeling at scales from the leaf to the globe. Global Biogeochemical Cycles 16, 1060.

Kaplan, J.O., Bigelow, N.H., Prentice, I.C., Harrison, S.P., Barlein, P.J., Christensen, T.R., Cramer, W., Matveyeva, N.V., McGuire, A.D., Murray, D.F., Razzhivin, V.Y., Smith, B., Walker, D.A., Anderson, P.M., Andreev, A.A., Brubaker, L.B., Edwards, M.E., Lozhkin, A.V., 2003. Climate change and Arctic ecosystems: 2. Modeling, paleodata-model comparisons, and future projections. Journal of Geophysical Research 108, No. D19, 8171.

Kerstiens, G., 1996. Plant cuticles: an integrated functional approach. BIOS Scientific Publishers, Oxford. Koch, K., Ensikat, H.J., 2008. The hydrophobic coatings of plant surfaces: Epicuticular wax crystals and their morphologies, crystallinity and molecular self-assembly. Micron 39, 759-772.

Koch, P.L., 1998. Isotopic reconstruction of past continental environments. Annual Review of Earth and Planetary Sciences 26, 573-613.

Kohn, M.J., 2010. Carbon isotope compositions of terrestrial $C_{3}$ plants as indicators of (paleo)ecology and (paleo)climate. Proceedings of the National Academy of Sciences of the USA.

Kolattukudy, P., Croteau, R., Buckner, J., 1976. Biochemistry of plant waxes. In: Kolattukudy, P. (Ed.), | Chemistry and Biochemistry of Natural Waxes. Elsevier, pp. 289-347.

Kolattukudy, P., 1996. Biosynthetic pathways of cutin and waxes, their sensitivity to environmental stresses. In: Kersteins, G. (Ed.), Plant Cuticles, An Integrated Functional Approach. BIOS Scientific Publishers Ltd., pp. 83-108.

Körner, C., 2007. The use of 'altitude' in ecological research. Trends in Ecology \& Evolution 22, 569-574. Körner, C.H., Farquhar, G.D., Wong, S.C., 1991. Carbon isotope discrimination by plants follows latitudinal and altitudinal trends. Oecologia 88, 30-40. 
Krishnan, S., Pagani, M., Agnini, C., 2015. Leaf waxes as recorders of paleoclimatic changes during the Paleocene-Eocene Thermal Maximum: Regional expressions from the Belluno Basin. Organic Geochemistry 80, 8-17.

Krull, E., Sachse, D., Mügler, I., Thiele, A., Gleixner, G., 2006. Compound-specific $\delta^{13} \mathrm{C}$ and $\delta^{2} \mathrm{H}$ analyses of plant and soil organic matter: A preliminary assessment of the effects of vegetation change on ecosystem hydrology. Soil Biology and Biochemistry 38, 3211-3221.

Kump, L.R., Arthur, M.A., 1999. Interpreting carbon-isotope excursions: carbonates and organic matter. Chemical Geology 161, 181-198.

Kunst, L., Samuels, A.L., 2003. Biosynthesis and secretion of plant cuticular wax. Progress in Lipid Research 42, 51-80.

Kusch, S., Rethemeyer, J., Schefuß, E., Mollenhauer, G., 2010. Controls on the age of vascular plant biomarkers in Black Sea sediments. Geochimica et Cosmochimica Acta 74, 7031-7047.

Ladd, B., Peri, P.L., Pepper, D.A., Silva, L.C.R., Sheil, D., Bonser, S.P., Laffan, S.W., Amelung, W., Ekblad, A., Eliasson, P., Bahamonde, H., Duarte-Guardia, S., Bird, M., 2014. Carbon isotopic signatures of soil organic matter correlate with leaf area index across woody biomes. Journal of Ecology 102, 1606-1611.

Lammertsma, E.I., Boer, H.J.d., Dekker, S.C., Dilcher, D.L., Lotter, A.F., Wagner-Cremer, F., 2011. Global $\mathrm{CO}_{2}$ rise leads to reduced maximum stomatal conductance in Florida vegetation.

| Proceedings of the National Academy of Sciences of the USA108, 4035-4040.

Leavitt, S.W., Newberry, T., 1992. Systematics of stable-carbon isotopic differences between gymnosperm and angiosperm trees. Plant Physiology 11, 257-262.

Leslie, A.B., Beaulieu, J.M., Rai, H.S., Crane, P.R., Donoghue, M.J., Mathews, S., 2012. Hemispherescale differences in conifer evolutionary dynamics. Proceedings of the National Academy of | Sciences of the USA109, 16217-16221.

Lichtfouse, E., 2011. ${ }^{13} \mathrm{C}$-dating, the first method to calculate the relative age of molecular substance homologues in soil. Environmental Chemistry Letters 10, 97-103.

Lloyd, J., Farquhar, G.D., 1994. ${ }^{13} \mathrm{C}$ discrimination during $\mathrm{CO}_{2}$ assimilation by the terrestrial biosphere. Oecologia 99, 201-215. 
Lockheart, M.J., Van Bergen, P.F., Evershed, R.P., 1997. Variations in the stable carbon isotope compositions of individual lipids from the leaves of modern angiosperms: implications for the study of higher land plant-derived sedimentary organic matter. Organic Geochemistry 26, 137-153.

Lockheart, M.J., Poole, I., van Bergen, P.F., Evershed, R.P., 1998. Leaf carbon isotope compositions and stomatal characters: important considerations for palaeoclimate reconstructions. Organic Geochemistry 29, 1003-1008.

Logan, G.A., Smiley, C.J., Eglinton, G., 1995. Preservation of fossil leaf waxes in association with their source tissues, Clarkia, northern Idaho, USA. Geochimica et Cosmochimica Acta 59, 751-763.

Lüttge, U., 2004. Ecophysiology of crassulacean acid metabolism (CAM). Annals of Botany 93, 629-652.

Lytle, T.F., Lytle, J.S., Caruso, A., 1976. Hydrocarbons and fatty acids of ferns. Phytochemistry 15, 965-970.

Magill, C.R., Ashley, G.M., Freeman, K.H., 2013. Ecosystem variability and early human habitats in eastern Africa. Proceedings of the National Academy of Sciences of the USA110, 1167-1174.

Marwick, T.R., Borges, A.V., Van Acker, K., Darchambeau, F., Bouillon, S., 2014. Disproportionate contribution of riparian inputs to organic carbon pools in freshwater systems. Ecosystems 17, 974-989.

McInerney, F.A., Wing, S.L., 2011. The Paleocene-Eocene Thermal Maximum: A perturbation of carbon cycle, climate, and biosphere with implications for the future. Annual Review of Earth and Planetary Sciences 39, 489-516.

McQueen, D.R., 1969. Macroscopic plant remains in Recent lake sediments. Tuatara 17, 13-19.

Mead, R., Xu, Y., Chong, J., Jaffé, R., 2005. Sediment and soil organic matter source assessment as revealed by the molecular distribution and carbon isotopic composition of $n$-alkanes. Organic Geochemistry 36, 363-370.

Meyers, P.A., Bourbonniere, R.A., Takeuchi, N., 1980. Hydrocarbons and fatty acids in two cores of Lake Huron sediments. Geochimica et Cosmochimica Acta 44, 1215-1221.

Meyers, P.A., Hites, R.A., 1982. Extractable organic compounds in midwest rain and snow. Atmospheric Environment 16, 2169-2175. 
Meyers, P.A., Ishiwatari, R., 1993. Lacustrine organic geochemistry—an overview of indicators of organic matter sources and diagenesis in lake sediments. Organic Geochemistry 20, 867-900.

Mollenhauer, G., Eglinton, T.I., 2007. Diagenetic and sedimentological controls on the composition of organic matter preserved in California Borderland Basin sediments. Limnology and Oceanography 52, 558-576.

Mortazavi, B., Conte, M.H., Chanton, J.P., Weber, J.C., Martin, T.A., Cropper, W.P., 2012. Variability in the carbon isotopic composition of foliage carbon pools (soluble carbohydrates, waxes) and respiration fluxes in southeastern U.S. pine forests. Journal of Geophysical Research: Biogeosciences 117, n/a-n/a.

Mösle, B., Finch, P., Collinson, M.E., Scott, A.C., 1997. Comparison of modern and fossil plant cuticles by selective chemical extraction monitored by flash pyrolysis-gas chromatography-mass spectrometry and electron microscopy. Journal of Analytical and Applied Pyrolysis 40-41, 585-597.

Mösle, B., Collinson, M.E., Finch, P., Stankiewicz, B.A., Scott, A.C., Wilson, R., 1998. Factors influencing the preservation of plant cuticles: a comparison of morphology and chemical composition of modern and fossil examples. Organic Geochemistry 29, 1369-1380.

Mueller, K.E., Polissar, P.J., Oleksyn, J., Freeman, K.H., 2012. Differentiating temperate tree species and their organs using lipid biomarkers in leaves, roots and soil. Organic Geochemistry 52, 130-141.

Muller, C., Riederer, M., 2005. Plant surface properties in chemical ecology. Journal of Chemical Ecology $31,2621-2651$.

Murray, A.P., Edwards, D., Hope, J.M., Boreham, C.J., Booth, W.E., Alexander, R.A., Summons, R.E., 1998. Carbon isotope biogeochemistry of plant resins and derived hydrocarbons. Organic Geochemistry 29, 1199-1214.

Nguyen Tu, T.T., Derenne, S., Largeau, C., Bardoux, G., Mariotti, A., 2004a. Diagenesis effects on specific carbon isotope composition of plant $n$-alkanes. Organic Geochemistry 35, 317-329.

Nguyen Tu, T.T., Kürschner, W.M., Schouten, S., Van Bergen, P.F., 2004b. Leaf carbon isotope composition of fossil and extant oaks grown under differing atmospheric $\mathrm{CO}_{2}$ levels. Palaeogeography, Palaeoclimatology, Palaeoecology 212, 199-213. 
Nguyen Tu, T.T., Egasse, C., Zeller, B., Bardoux, G., Biron, P., Ponge, J.-F., David, B., Derenne, S., 2011. Early degradation of plant alkanes in soils: A litterbag experiment using 13C-labelled leaves. Soil Biology and Biochemistry 43, 2222-2228.

Nichols, J.E., Booth, R.K., Jackson, S.T., Pendall, E.G., Huang, Y., 2006. Paleohydrologic reconstruction based on $n$-alkane distributions in ombrotrophic peat. Organic Geochemistry 37, 1505-1513.

Nott, C.J., Xie, S., Avsejs, L.A., Maddy, D., Chambers, F.M., Evershed, R.P., 2000. n-Alkane distributions in ombrotrophic mires as indicators of vegetation change related to climatic variation. Organic Geochemistry 31, 231-235.

O'Leary, M.H., 1981. Carbon isotope fractionation in plants. Phytochemistry 20, 553-567.

Pagani, M., Pedentchouk, N., Huber, M., Sluijs, A., Schouten, S., Brinkhuis, H., Sinninghe Damste, J.S., Dickens, G.R., Scienctists, t.e., 2006. Arctic hydrology during global warming at the Palaeocene/ Eocene thermal maximum. Nature 442, 671-675.

Pancost, R.D., Baas, M., van Geel, B., Sinninghe DamstÈ, J.S., 2002. Biomarkers as proxies for plant inputs to peats: an example from a sub-boreal ombrotrophic bog. Organic Geochemistry 33, 675-690.

Pancost, R.D., Boot, C.S., 2004. The palaeoclimatic utility of terrestrial biomarkers in marine sediments. Marine Chemistry 92, 239-261.

Parker, G., O'Neill, J., Higman, D., 1989. Vertical profile and canopy organization in a mixed deciduous forest. Vegetatio 85, 1-11.

Pearson, A., Eglinton, T.I., 2000. The origin of $n$-alkanes in Santa Monica Basin surface sediment: a model based on compound-specific $\Delta^{14} \mathrm{C}$ and $\delta^{13} \mathrm{C}$ data. Organic Geochemistry 31, 1103-1116.

Pearson, A., McNichol, A.P., Benitez-Nelson, B.C., Hayes, J.M., Eglinton, T.I., 2001. Origins of lipid biomarkers in Santa Monica Basin surface sediment: A case study using compound-specific $\Delta 14 \mathrm{C}$ analysis. Geochimica et Cosmochimica Acta 65, 3123-3137.

Peñuelas, J., Azcónbieto, J., 1992. Changes in leaf $\Delta{ }^{13} \mathrm{C}$ of herbarium plant-species during the last 3 centuries of $\mathrm{CO}_{2}$ Increase. Plant Cell and Environment 15, 485-489.

Peters-Kottig, W., Strauss, H., Kerp, H., 2006. The land plant $\delta^{13} \mathrm{C}$ record and plant evolution in the Late Palaeozoic. Palaeogeography, Palaeoclimatology, Palaeoecology 240, 237-252. 
Polissar, P., Preefer, M., Liu, C., (2014) Fidelity of leaf-wax $n$-alkane and $n$-alkanoic acid D/H ratios in space and time. In: American Geophysical Union, pp. PP43E-07.

Polissar, P.J., Freeman, K.H., 2010. Effects of aridity and vegetation on plant-wax $\delta \mathrm{D}$ in modern lake sediments. Geochimica et Cosmochimica Acta 74, 5785-5797.

Polissar, P.J., D’Andrea, W.J., 2014. Uncertainty in paleohydrologic reconstructions from molecular $\delta \mathrm{D}$ values. Geochimica et Cosmochimica Acta 129, 146-156.

Polley, H.W., Johnson, H.B., Mayeux, H.S., 1995. Nitrogen and water requirements of $\mathrm{C}_{3}$ plants grown at glacial to present carbon dioxide concentrations. Functional Ecology 9, 86-96.

Ponton, C., West, A.J., Feakins, S.J., Galy, V., 2014. Leaf wax biomarkers in transit record river catchment composition. Geophysical Research Letters 41, 6420-6427.

Powell, T.G., McKirdy, D.M., 1973. The effect of source material, rock type and diagenesis on the nalkane content of sediments. Geochimica et Cosmochimica Acta 37, 623-633.

Prahl, F.G., Cowie, G.L., De Lange, G.J., Sparrow, M.A., 2003. Selective organic matter preservation in "burn-down" turbidites on the Madeira Abyssal Plain. Paleoceanography 18, n/a-n/a.

Prentice, I.C., 1985. Pollen representation, source area, and basin size: Toward a unified theory of pollen analysis. Quaternary Research 23, 76-86.

Prentice, I.C., Harrison, S.P., Bartlein, P.J., 2011a. Global vegetation and terrestrial carbon cycle changes after the last ice age. New Phytologist 189, 988-998.

Prentice, I.C., Meng, T., Wang, H., Harrison, S.P., Ni, J., Wang, G., 2011b. Evidence of a universal scaling relationship for leaf $\mathrm{CO}_{2}$ drawdown along an aridity gradient. New Phytologist 190, 169-180.

Rai, H.S., Reeves, P.A., Peakall, R., Olmstead, R.G., Graham, S.W., 2008. Inference of higher-order conifer relationships from a multi-locus plastid data set. Botany 86, 658-669.

Reich, P.B., Uhl, C., Walters, M.B., Ellsworth, D.S., 1991. Leaf lifespan as a determinant of leaf structure and function among 23 amazonian tree species. Oecologia 86, 16-24.

Riederer, M., Schreiber, L., 2001. Protecting against water loss: analysis of the barrier properties of plant cuticles. Journal of Experimental Botany 52, 2023-2032.

Riederer, M., Muller, C., (2006) Biology of the plant cuticle, pp. 438. Blackwell Publishing, Oxford. 
Rieley, G., Collier, R.J., Jones, D.M., Eglinton, G., 1991. The biogeochemistry of Ellesmere Lake, UK. 1. Source correlation of leaf wax inputs to the sedimentary lipid record. Organic Geochemistry 17, 901-912.

Rommerskirchen, F., Plader, A., Eglinton, G., Chikaraishi, Y., Rullkötter, J., 2006. Chemotaxonomic significance of distribution and stable carbon isotopic composition of long-chain alkanes and alkan-1-ols in $\mathrm{C}_{4}$ grass waxes. Organic Geochemistry 37, 1303-1332.

Sachse, D., Radke, J., Gleixner, G., 2006. $\delta$ D values of individual $n$-alkanes from terrestrial plants along a climatic gradient - Implications for the sedimentary biomarker record. Organic Geochemistry 37, 469-483.

Sachse, D., Billault, I., Bowen, G.J., Chikaraishi, Y., Dawson, T.E., Feakins, S.J., Freeman, K.H., Magill, C.R., McInerney, F.A., van der Meer, M.T.J., Polissar, P., Robins, R.J., Sachs, J.P., Schmidt, H.L., Sessions, A.L., White, J.W.C., West, J.B., Kahmen, A., 2012. Molecular paleohydrology: Interpreting the hydrogen-isotopic composition of lipid biomarkers from photosynthesizing organisms. Annual Review of Earth and Planetary Sciences 40, 221-249.

Sage, R.F., Wedin, D.A., Li, M., 1999. The biogeography of $\mathrm{C}_{4}$ photosynthesis: patterns and controlling factors. In: Sage, R.F., Monson, R.K. (Eds.), C4 Plant Biology. Academic Press, pp. 313-373.

Saurer, M., Siegwolf, R.T.W., Schweingruber, F.H., 2004. Carbon isotope discrimination indicates improving water-use efficiency of trees in northern Eurasia over the last 100 years. Global Change Biology 10, 2109-2120.

Schefuß, E., Ratmeyer, V., Stuut, J.-B.W., Jansen, J.H.F., Sinninghe Damsté, J.S., 2003. Carbon isotope analyses of $n$-alkanes in dust from the lower atmosphere over the central eastern Atlantic. Geochimica et Cosmochimica Acta 67, 1757-1767.

Schefuß, E., Versteegh, G.J.M., Jansen, J.H.F., Sinninghe Damsté, J.S., 2004. Lipid biomarkers as major source and preservation indicators in SE Atlantic surface sediments. Deep Sea Research Part I: Oceanographic Research Papers 51, 1199-1228.

Schefuß, E., Eglinton, T.I., Spencer-Jones, C.L., Rullkötter, J., De Pol-Holz, R., Talbot, H.M., Grootes, P.M., Schneider, R.R., 2016. Hydrologic control of carbon cycling and aged carbon discharge in the Congo River basin. Nature Geoscience 9, 687-690. 
Schoon, P.L., Heilmann-Clausen, C., Schultz, B.P., Sinninghe Damsté, J.S., Schouten, S., 2015. Warming and environmental changes in the eastern North Sea Basin during the Palaeocene-Eocene Thermal Maximum as revealed by biomarker lipids. Organic Geochemistry 78, 79-88.

Schouten, S., Woltering, M., Rijpstra, W.I.C., Sluijs, A., Brinkhuis, H., Sinninghe Damste, J.S., 2007. The Paleocene-Eocene carbon isotope excursion in higher plant organic matter: Differential fractionation of angiosperms and conifers in the Arctic. Earth and Planetary Science Letters 258, 581-592.

Schubert, B.A., Jahren, A.H., 2012. The effect of atmospheric $\mathrm{CO}_{2}$ concentration on carbon isotope fractionation in $\mathrm{C}_{3}$ land plants. Geochimica et Cosmochimica Acta 96, 29-43.

Schwab, V.F., Garcin, Y., Sachse, D., Todou, G., Séné, O., Onana, J.-M., Achoundong, G., Gleixner, G., 2015. Effect of aridity on $\delta^{13} \mathrm{C}$ and $\delta \mathrm{D}$ values of $\mathrm{C}_{3}$ plant- and $\mathrm{C}_{4}$ graminoid-derived leaf wax lipids from soils along an environmental gradient in Cameroon (Western Central Africa). Organic Geochemistry 78, 99-109.

Seibt, U., Rajabi, A., Griffiths, H., Berry, J., 2008. Carbon isotopes and water use efficiency: sense and sensitivity. Oecologia 155, 441-454.

Seki, O., Nakatsuka, T., Shibata, H., Kawamura, K., 2010. A compound-specific n-alkane $\delta^{13} \mathrm{C}$ and $\delta \mathrm{D}$ approach for assessing source and delivery processes of terrestrial organic matter within a forested watershed in northern Japan. Geochimica et Cosmochimica Acta 74, 599-613.

Sessions, A.L., 2016. Factors controlling the deuterium contents of sedimentary hydrocarbons. Organic Geochemistry 96, 43-64.

Shepherd, T., Wynne Griffiths, D., 2006. The effects of stress on plant cuticular waxes. New Phytologist $171,469-499$.

Sikes, E.L., Medeiros, P.M., Augustinus, P., Wilmshurst, J.M., Freeman, K.R., 2013. Seasonal variations in aridity and temperature characterize changing climate during the last deglaciation in New Zealand. Quaternary Science Reviews 74, 245-256.

Simoneit, B.R., 2002. Biomass burning - a review of organic tracers for smoke from incomplete combustion. Applied Geochemistry 17, 129-162. 
Simoneit, B.R.T., 1977. Organic matter in eolian dusts over the Atlantic Ocean. Marine Chemistry 5, 443-464.

Simoneit, B.R.T., Chester, R., Eglinton, G., 1977. Biogenic lipids in particulates from lower atmosphere over eastern Atlantic. Nature 267, 682-685.

Simoneit, B.R.T., Mazurek, M.A., 1982. Organic-matter of the troposphere-II. Natural background of biogenic lipid matter in aerosols over the rural western United States. Atmospheric Environment $16,2139-2159$.

Simoneit, B.R.T., Cox, R.E., Standley, L.J., 1988. Organic matter of the troposphere-IV. Lipids in harmattan aerosols of nigeria. Atmospheric Environment 22, 983-1004.

Sinninghe Damsté, J.S., Rijpstra, W.I.C., Reichart, G.-j., 2002. The influence of oxic degradation on the sedimentary biomarker record II. Evidence from Arabian Sea sediments. Geochimica et Cosmochimica Acta 66, 2737-2754.

Smittenberg, R.H., Hopmans, E.C., Schouten, S., Hayes, J.M., Eglinton, T.I., Sinninghe Damsté, J.S., 2004. Compound-specific radiocarbon dating of the varved Holocene sedimentary record of Saanich Inlet, Canada. Paleoceanography 19, n/a-n/a.

Spicer, R.A., 1981. The sorting and deposition of allochthonous plant material in a modern environment at Silwood Lake, Silwood Park, Berkshire, England. United States Geological Survey Professional Paper 1143, 1-77.

Spicer, R.A., Wolfe, A.P., 1987. Plant taphonomy of late Holocene deposits in Trinity (Clair Engle) Lake, northern California. Paleobiology 13, 227-245.

Standley, L.J., Simoneit, B.R., 1987. Characterization of extractable plant wax, resin, and thermally matured components in smoke particles from prescribed burns. Environmental Science \& Technology 21, 163-169.

Stankiewicz, B.A., Briggs, D.E.G., Michels, R., Collinson, M.E., Flannery, M.B., Evershed, R.P., 2000. Alternative origin of aliphatic polymer in kerogen. Geology 28, 559-562.

Stewart, G.R., Turnbull, M.H., Schmidt, S., Erskine, P.D., 1995. ${ }^{13} \mathrm{C}$ natural abundance in plant communities along a rainfall gradient: a biological integrator of water availability. Australian Journal of Plant Physiology 22, 51-55. 
Sun, Y., Chen, Z., Xu, S., Cai, P., 2005. Stable carbon and hydrogen isotopic fractionation of individual nalkanes accompanying biodegradation: evidence from a group of progressively biodegraded oils. Organic Geochemistry 36, 225-238.

Teeri, J., Stowe, L., Murawski, D., 1978. The climatology of two succulent plant families: Cactaceae and Crassulaceae. Canadian Journal of Botany 56, 1750-1758.

Tegelaar, E.W., de Leeuw, J.W., Derenne, S., Largeau, C., 1989. A reappraisal of kerogen formation. Geochimica et Cosmochimica Acta 53, 3103-3106.

Tierney, J.E., Tingley, M.P., 2014. A Bayesian, spatially-varying calibration model for the TEX86 proxy. Geochimica et Cosmochimica Acta 127, 83-106.

Tipple, B.J., Pagani, M., 2007. The early origins of terrestrial $\mathrm{C}_{4}$ photosynthesis. Annual Review of Earth and Planetary Sciences 35, 435-461.

Tipple, B.J., Meyers, S.R., Pagani, M., 2010. Carbon isotope ratio of Cenozoic $\mathrm{CO}_{2}$ : A comparative evaluation of available geochemical proxies. Paleoceanography 25, PA3202.

Tipple, B.J., Pagani, M., 2010. A 35 Myr North American Leaf-Wax Compound-Specific Carbon and Hydrogen Isotope Record: Implications for C4 Grasslands and Hydrologic Cycle Dynamics. Earth and Planetary Science Letters 299, 250-262.

Tipple, B.J., Pagani, M., Krishnan, S., Dirghangi, S.S., Galeotti, S., Agnini, C., Giusberti, L., Rio, D., 2011. Coupled high-resolution marine and terrestrial records of carbon and hydrologic cycles variations during the Paleocene-Eocene Thermal Maximum (PETM). Earth and Planetary Science Letters 311, 82-92.

Tipple, B.J., Pagani, M., 2013. Environmental control on eastern broadleaf forest species' leaf wax distributions and D/H ratios. Geochimica et Cosmochimica Acta 111, 64-77.

Uchikawa, J., Popp, B., Schoonmaker, J., Xu, L., 2008. Direct application of compound-specific radiocarbon analysis of leaf waxes to establish lacustrine sediment chronology. Journal of Paleolimnology 39, 43-60.

Uno, K.T., Polissar, P.J., Jackson, K.E., deMenocal, P.B., 2016a. Neogene biomarker record of vegetation | change in eastern Africa. Proceedings of the National Academy of Sciences of the USA113, 6355-6363. 
Uno, K.T., Polissar, P.J., Kahle, E., Feibel, C., Harmand, S., Roche, H., deMenocal, P.B., 2016b. A Pleistocene palaeovegetation record from plant wax biomarkers from the Nachukui Formation, West Turkana, Kenya. Philosophical Transactions of the Royal Society B: Biological Sciences 371.

Vane, C., Kim, A., Cave, M., Li, N., 2014. Equal abundance of odd and even $n$-alkanes from cycad leaves: can the carbon preference index (CPI) faithfully record terrestrial organic matter input at low latitudes? Encephalartos 118, 10-13.

Voelker, S.L., Brooks, J.R., Meinzer, F.C., Anderson, R., Bader, M.K.F., Battipaglia, G., Becklin, K.M., Beerling, D., Bert, D., Betancourt, J.L., Dawson, T.E., Domec, J.-C., Guyette, R.P., Körner, C., Leavitt, S.W., Linder, S., Marshall, J.D., Mildner, M., Ogée, J., Panyushkina, I., Plumpton, H.J., Pregitzer, K.S., Saurer, M., Smith, A.R., Siegwolf, R.T.W., Stambaugh, M.C., Talhelm, A.F., Tardif, J.C., Van de Water, P.K., Ward, J.K., Wingate, L., 2016. A dynamic leaf gas-exchange strategy is conserved in woody plants under changing ambient $\mathrm{CO}_{2}$ : evidence from carbon isotope discrimination in paleo and $\mathrm{CO}_{2}$ enrichment studies. Global Change Biology 22, 889-902.

Vogts, A., Moossen, H., Rommerskirchen, F., Rullkötter, J., 2009. Distribution patterns and stable carbon isotopic composition of alkanes and alkan-1-ols from plant waxes of African rain forest and savanna $\mathrm{C}_{3}$ species. Organic Geochemistry 40, 1037-1054.

Vogts, A., Schefuß, E., Badewien, T., Rullkötter, J., 2012. n-Alkane parameters from a deep sea sediment transect off southwest Africa reflect continental vegetation and climate conditions. Organic Geochemistry 47, 109-119.

Vogts, A., Badewien, T., Rullkötter, J., Schefuß, E., 2016. Near-constant apparent hydrogen isotope fractionation between leaf wax $n$-alkanes and precipitation in tropical regions: Evidence from a marine sediment transect off SW Africa. Organic Geochemistry 96, 18-27.

Vonk, J.E., van Dongen, B.E., Gustafsson, Ö., 2010. Selective preservation of old organic carbon fluvially released from sub-Arctic soils. Geophysical Research Letters 37, n/a-n/a.

Wakeham, S.G., Lee, C., Hedges, J.I., Hernes, P.J., Peterson, M.J., 1997. Molecular indicators of diagenetic status in marine organic matter. Geochimica et Cosmochimica Acta 61, 5363-5369. 
Warren, C.R., McGrath, J.F., Adams, M.A., 2001. Water availability and carbon isotope discrimination in conifers. Oecologia 127, 476-486.

Warren, C.R., Adams, M.A., 2006. Internal conductance does not scale with photosynthetic capacity: implications for carbon isotope discrimination and the economics of water and nitrogen use in photosynthesis. Plant, Cell, and Environment 29, 192-201.

Wing, S.L., Bloch, J.I., Bowen, G.J., Boyer, D.M., Chester, S., Diefendorf, A.F., Harrington, G.J., Kraus, M.J., Secord, R., Smith, F.A., 2009. Coordinated sedimentary and biotic change during the Paleocene-Eocene Thermal Maximum in the Bighorn Basin, Wyoming, USA. In: Crouch, E.M., Strong, C.P., Hollis, C.J. (Eds.), Climatic and Biotic Events of the Paleogene (CBEP 2009), extended abstracts from an international conference in Wellington, New Zealand, 12-15 January 2009. GNS Science Miscellaneous Series 18, pp. 156-162.

Wolfe, J.A., Schorn, H.E., 1990. Taxonomic revision of the Spermatopsida of the Oligocene Creede flora, southern Colorado. U.S. Geological Survey Bulletin 1923.

Woodward, F.I., 1987. Stomatal numbers are senstitive to increased $\mathrm{CO}_{2}$ from pre-industrial levels. Nature 327, 617-618.

Woodward, F.I., Kelly, C.K., 1995. The influence of $\mathrm{CO}_{2}$ concentration on stomatal density. New Phytologist 131, 311-327.

Wright, I.J., Cannon, K., 2001. Relationships between leaf lifespan and structural defences in a lownutrient, sclerophyll flora. Functional Ecology 15, 351-359.

Wynn, J.G., Bird, M.I., Wong, V.N.L., 2005. Rayleigh distillation and the depth profile of 13C/12C ratios of soil organic carbon from soils of disparate texture in Iron Range National Park, Far North Queensland, Australia. Geochimica et Cosmochimica Acta 69, 1961-1973.

Wynn, J.G., 2007. Carbon isotope fractionation during decomposition of organic matter in soils and paleosols: Implications for paleoecological interpretations of paleosols. Palaeogeography, Palaeoclimatology, Palaeoecology 251, 437-448.

Zech, M., Rass, S., Buggle, B., Löscher, M., Zöller, L., 2012. Reconstruction of the late Quaternary paleoenvironments of the Nussloch loess paleosol sequence, Germany, using $n$-alkane biomarkers. Quaternary Research 78, 226-235. 
Figure 1

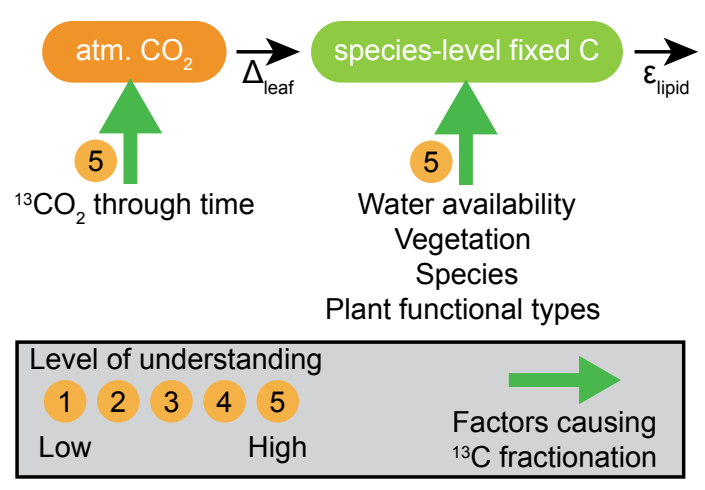

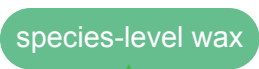

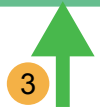

Lipid biosynthesis

Species

Climate? ecosystem-level leaf wax

$\downarrow$

sediment-level leaf wax

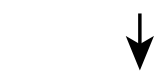

2 Species composition Ecosystem structure Biome type

Taphonomic processes Lipid source mixing (eolian) Basin dynamics/sediment transport Integration of reworked waxes 


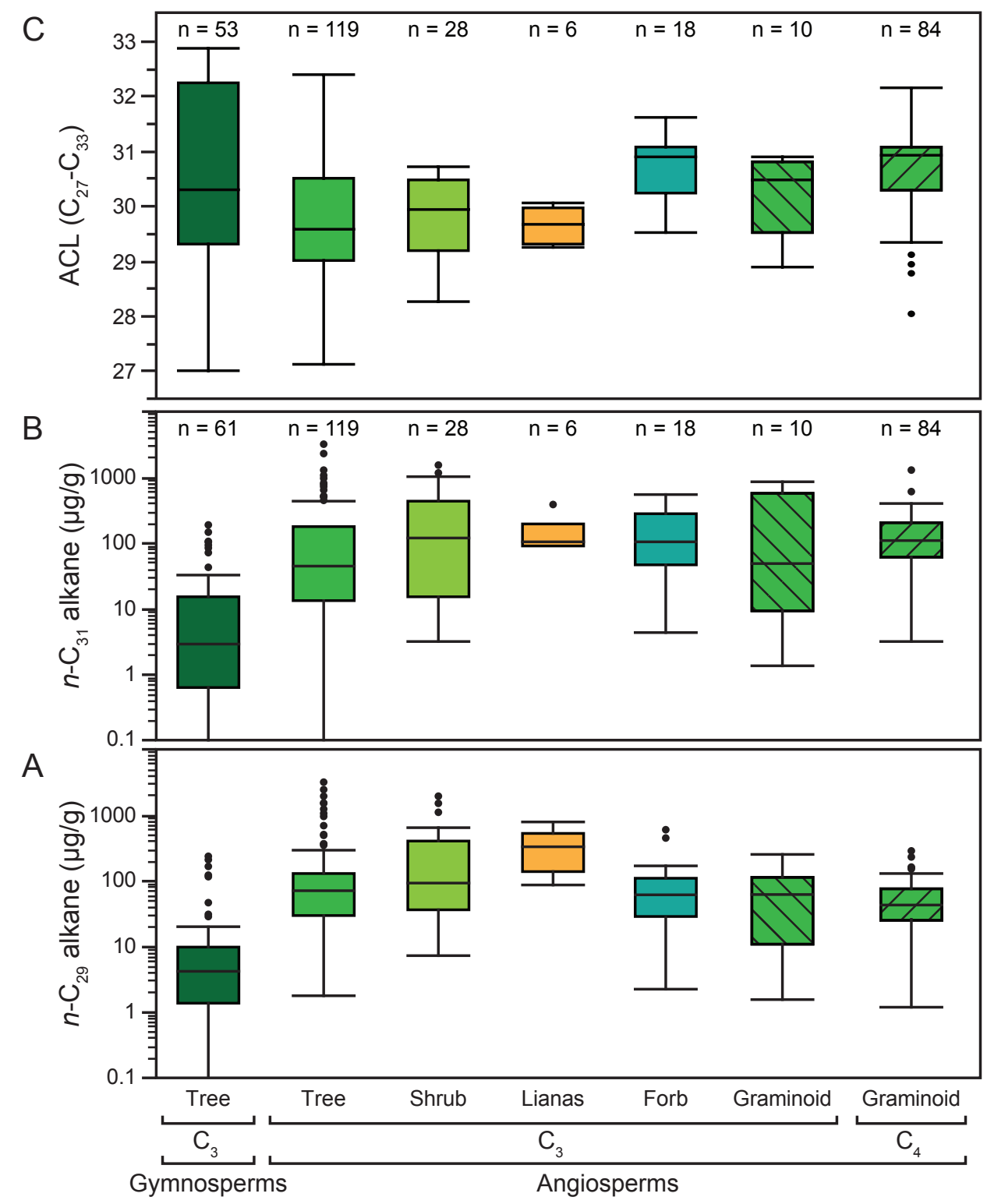




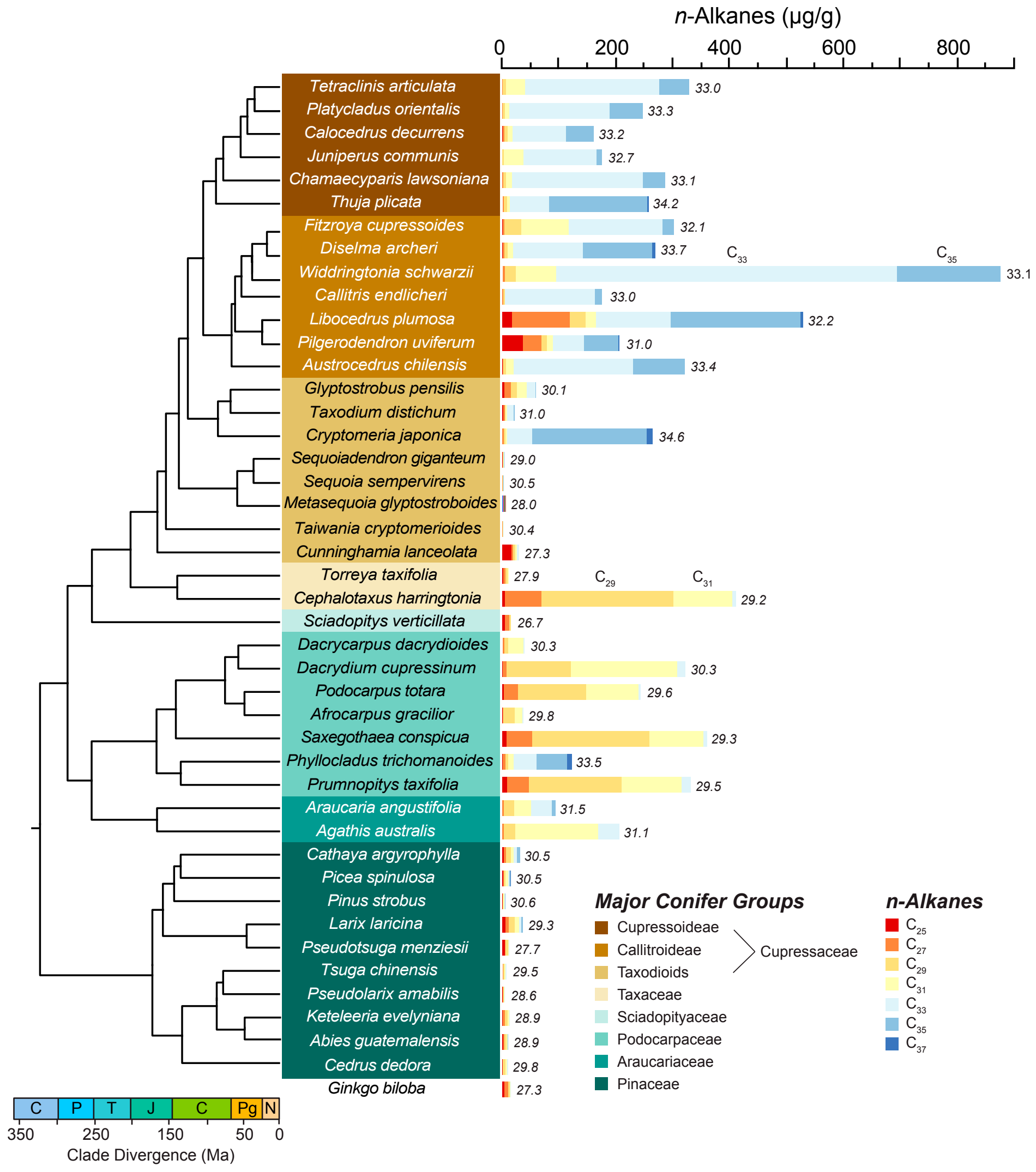




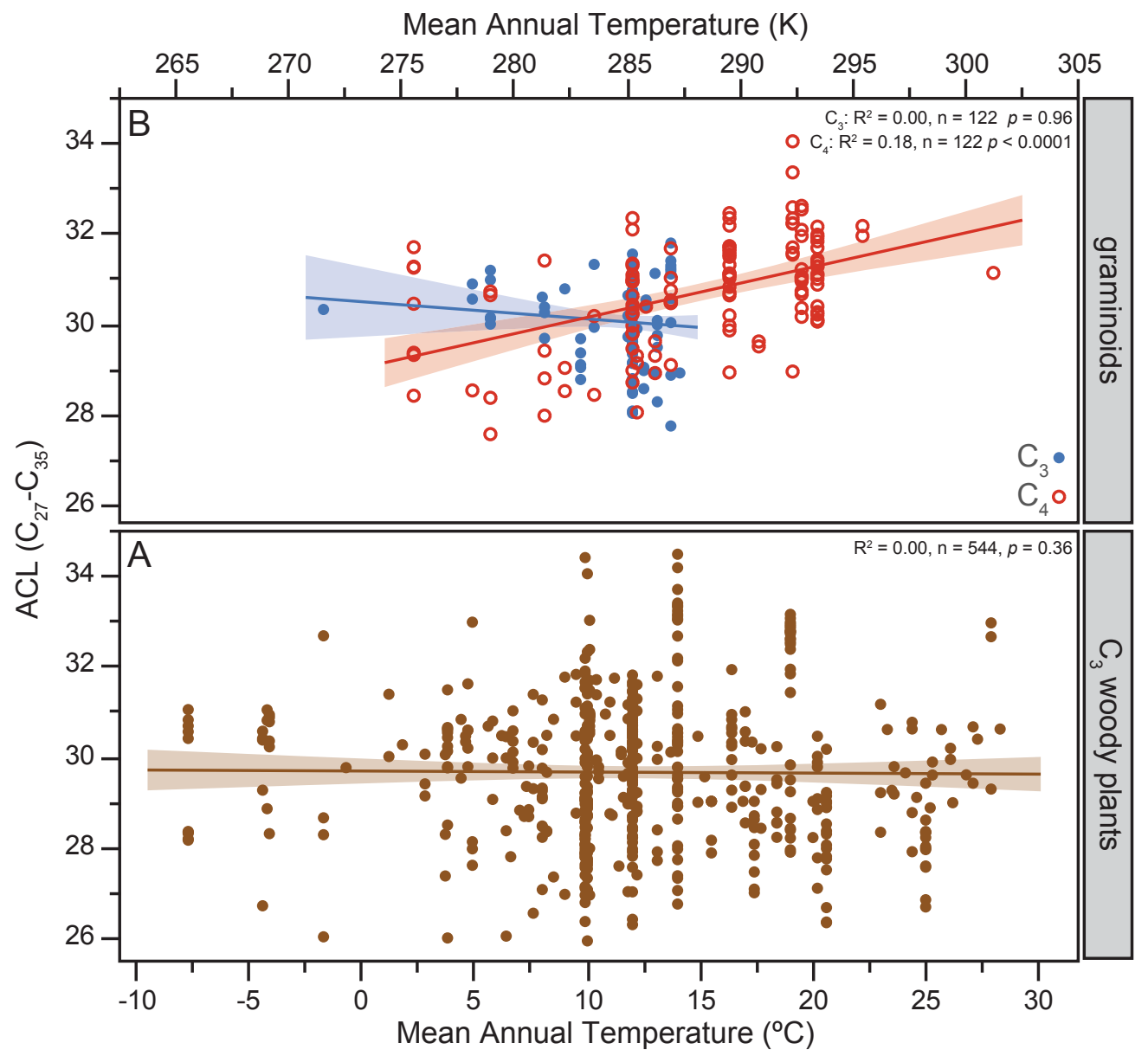


Figure 5

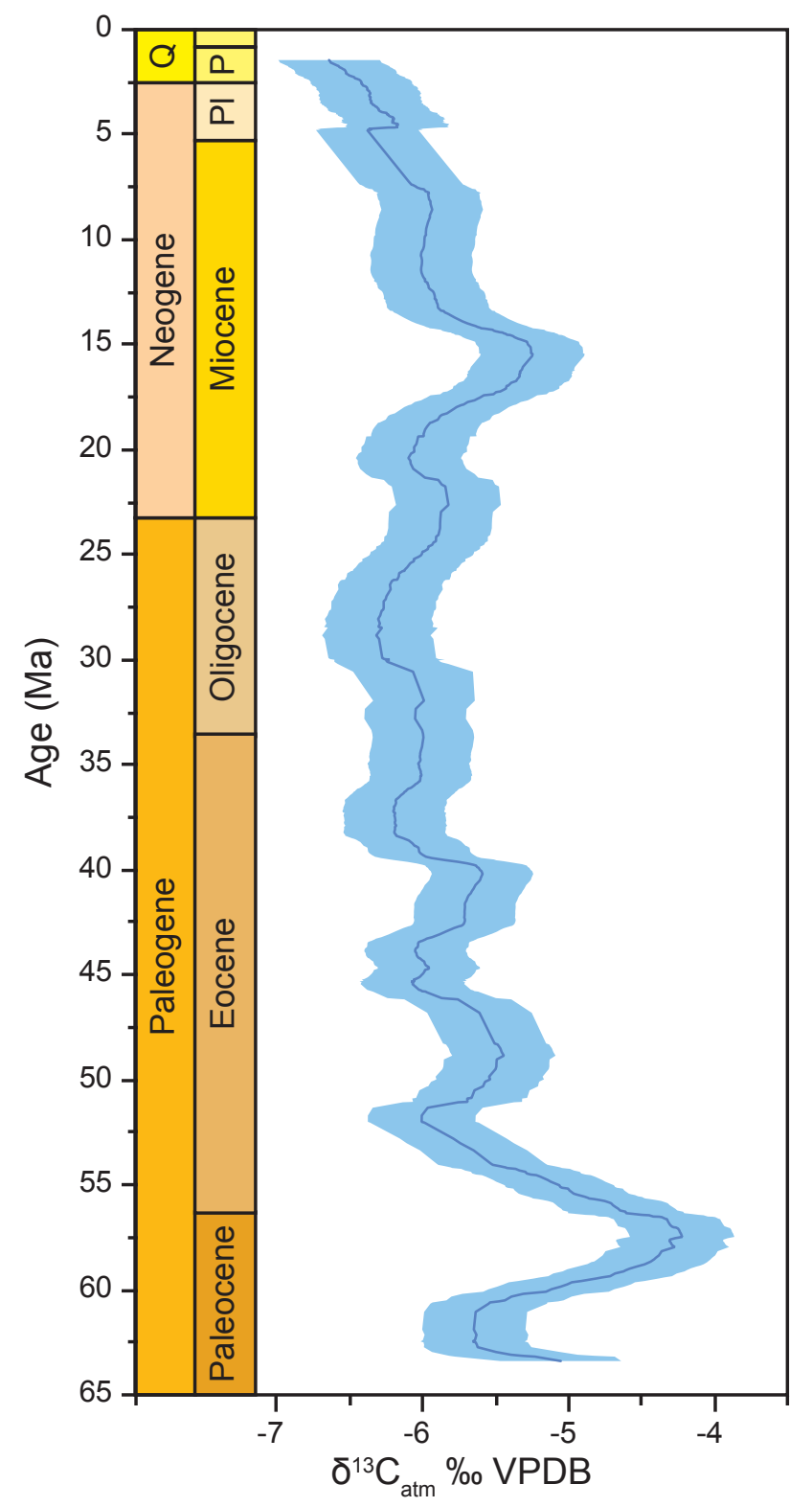




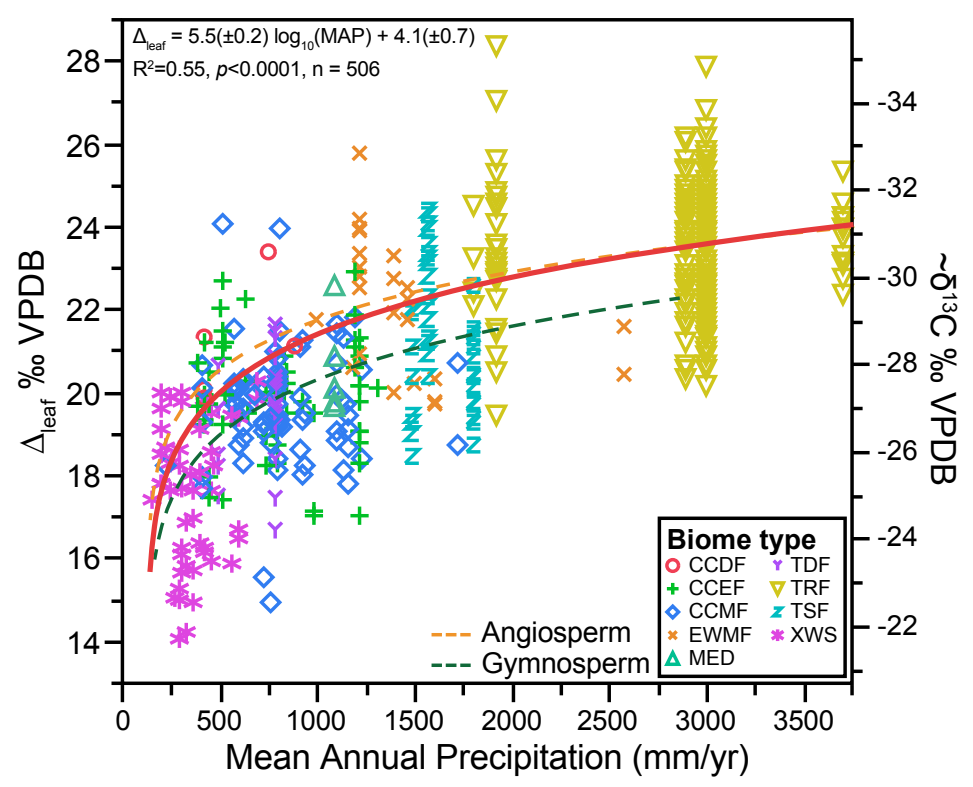


Figure 7.

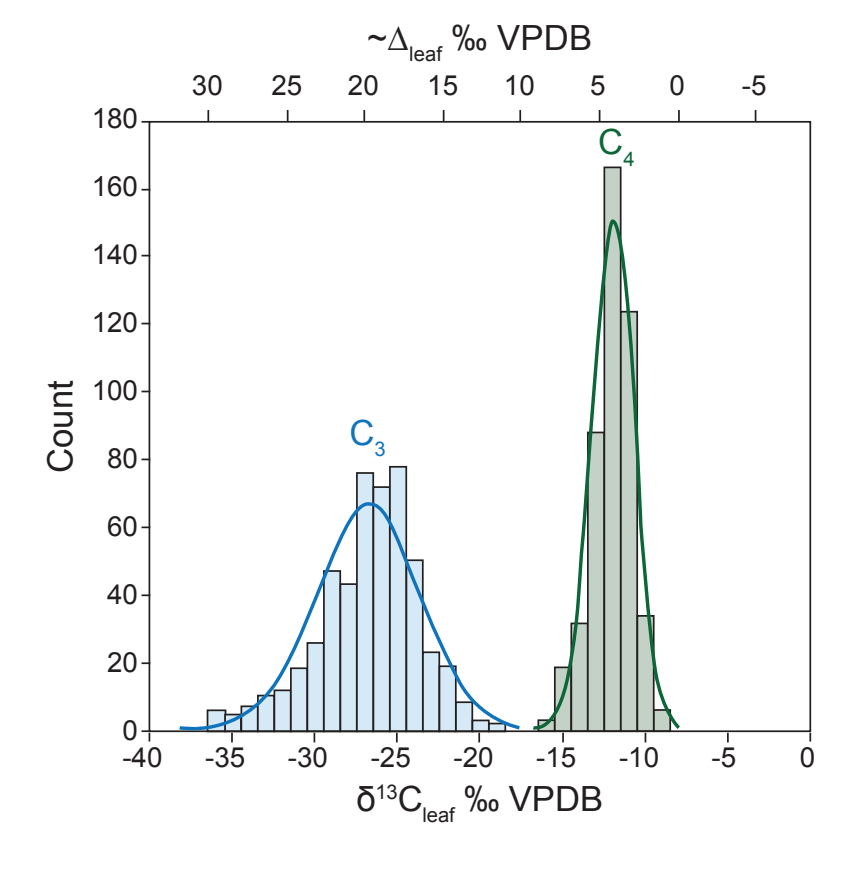

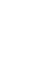

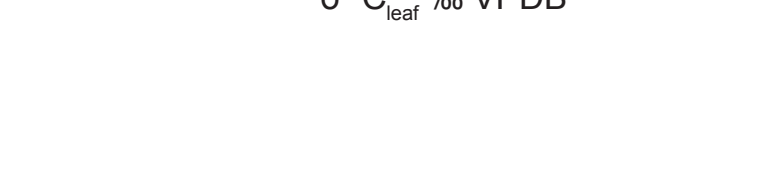


Figure 8

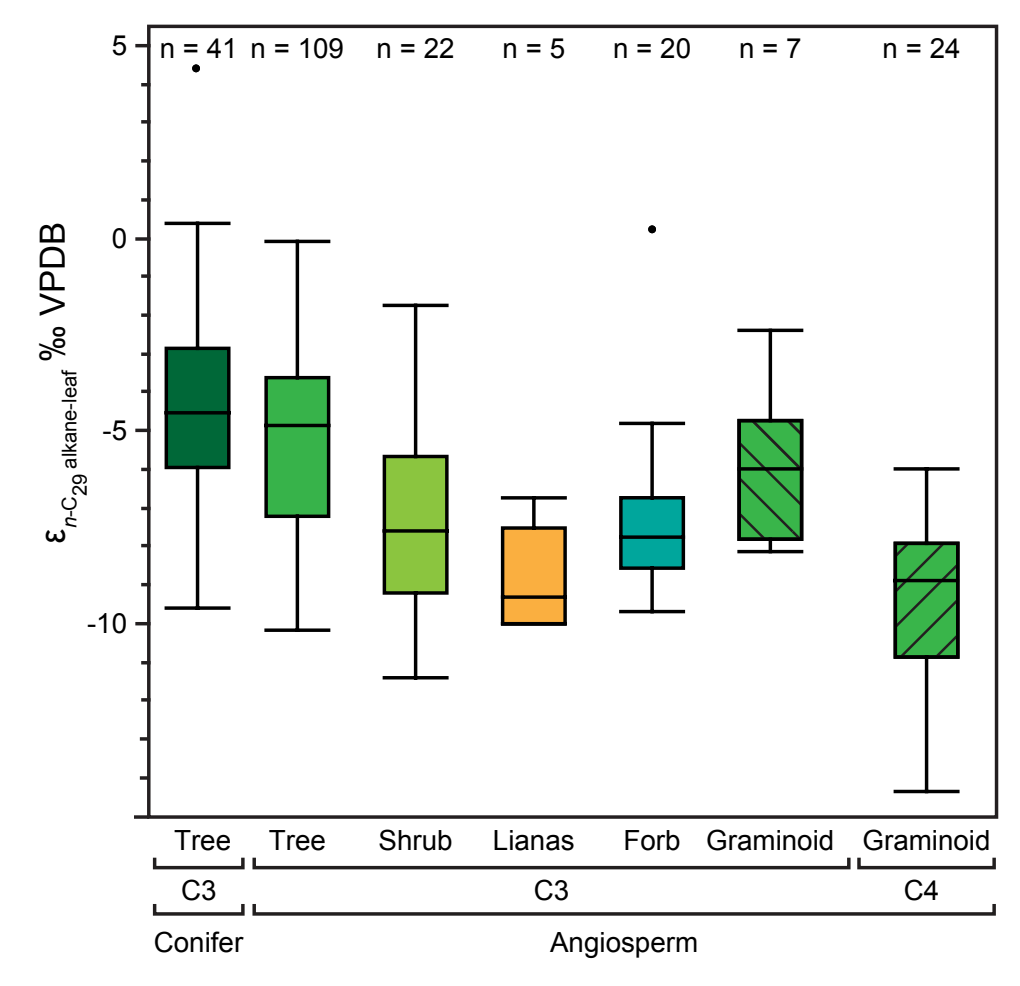

(10) $n=22 \quad n=5 \quad n=20 \quad n=7 \quad n=24$

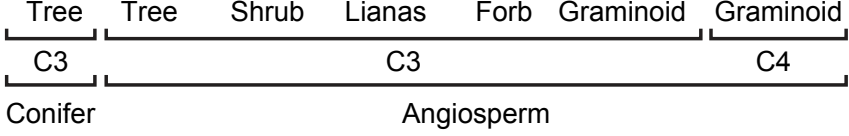


Figure 9

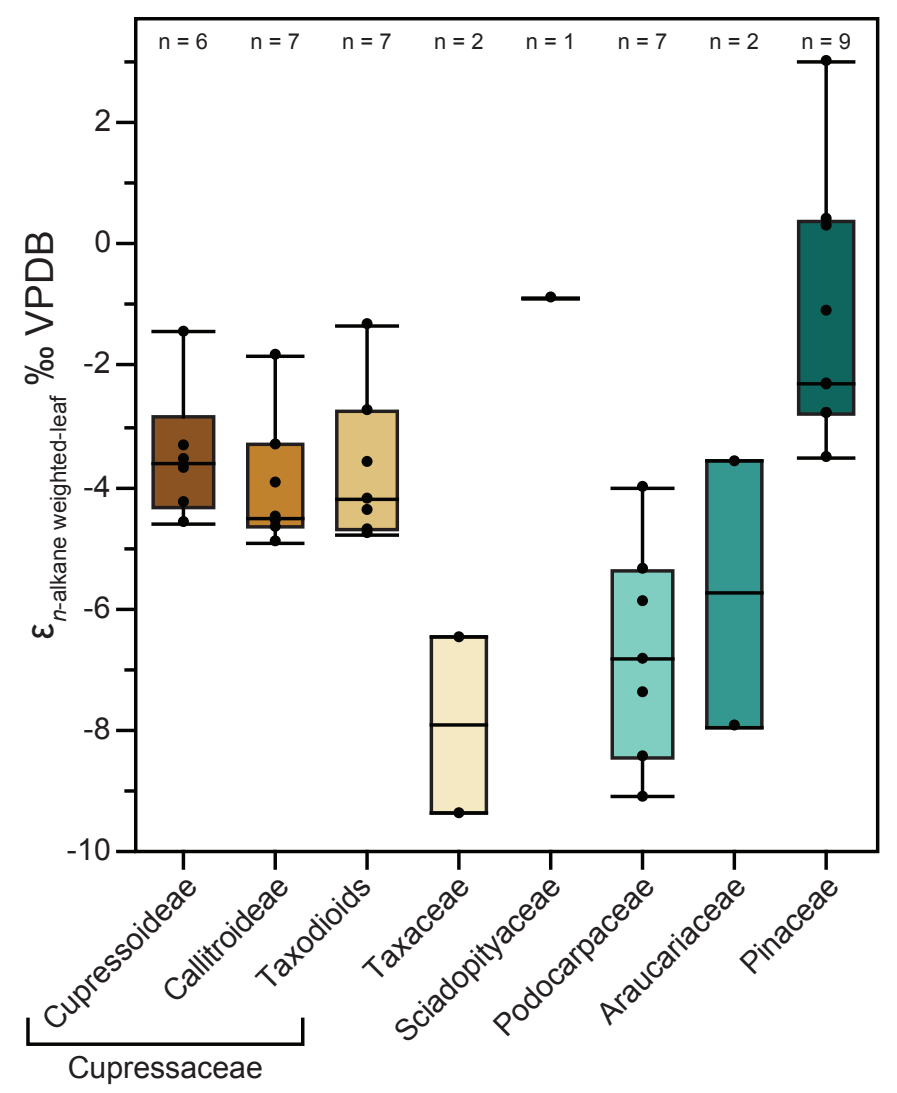




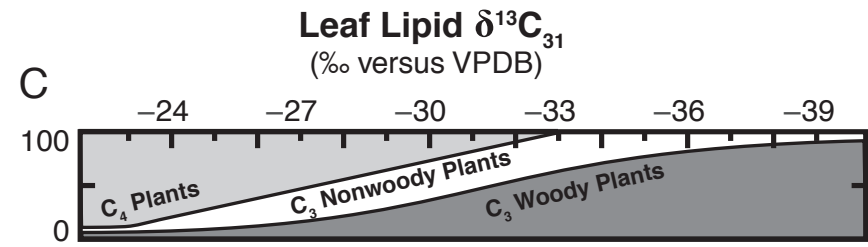

Plant Type

Abundance (percent)

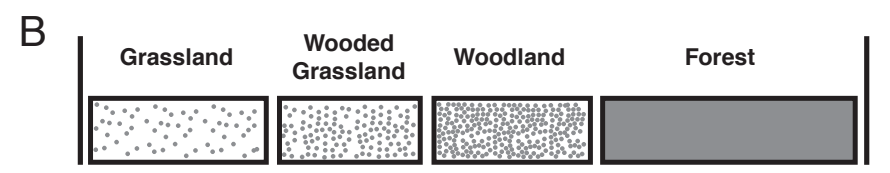

Ecosystem

A

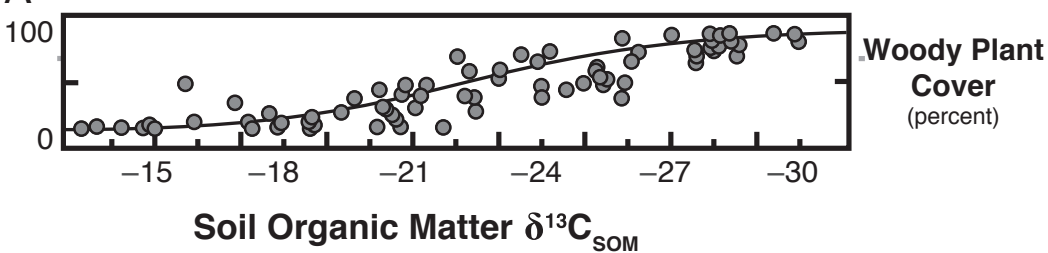

(\% versus VPDB) 

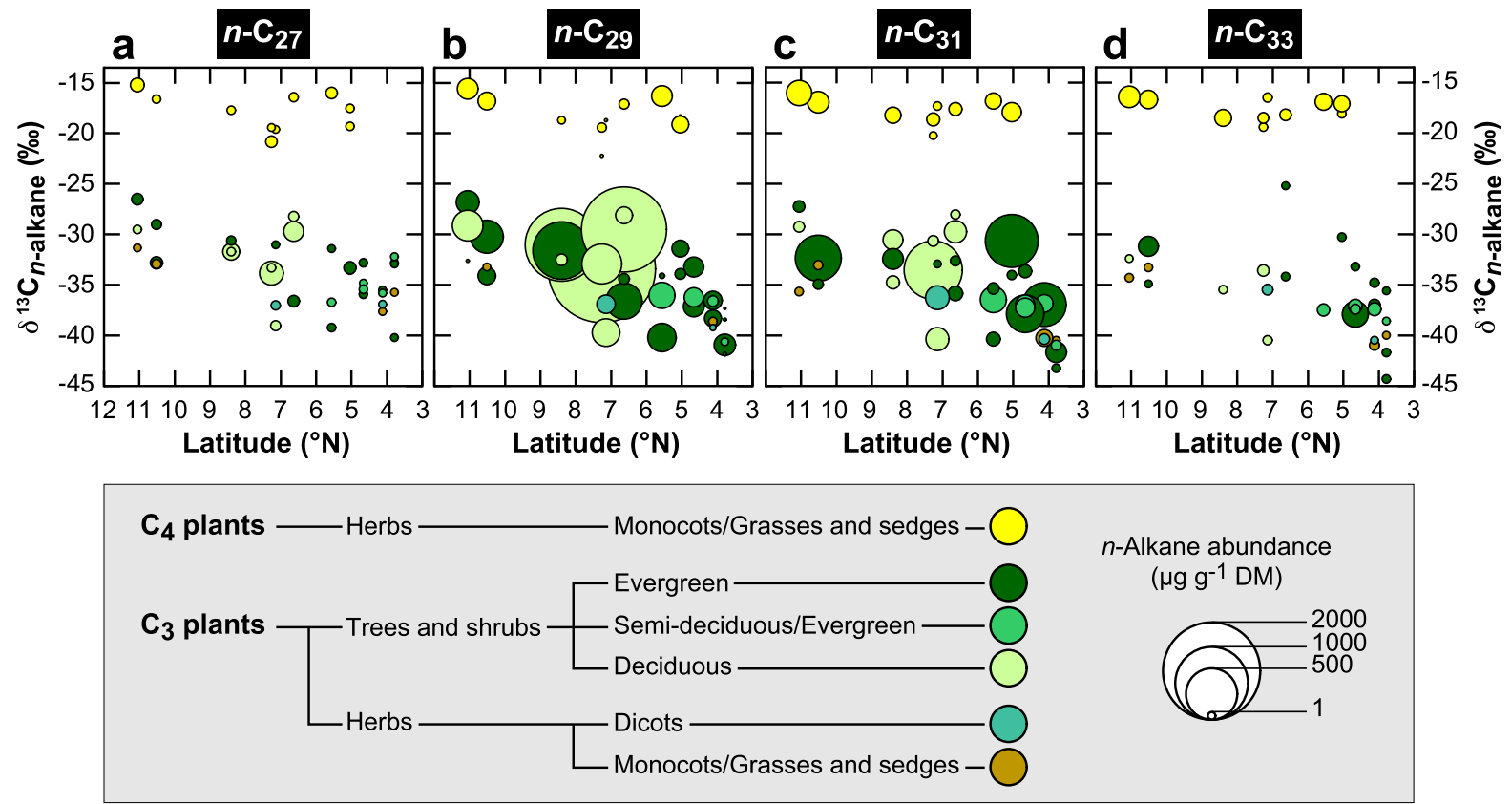